Key Words:

DWPF

Qualification

Retention:

Permanent

\title{
SLUDGE WASHING AND DEMONSTRATION OF THE DWPF FLOWSHEET IN THE SRNL SHIELDED CELLS FOR SLUDGE BATCH 5 QUALIFICATION
}

\author{
J. M. Pareizs \\ C. J. Bannochie \\ D. R. Click \\ D. P. Lambert \\ M. E. Stone \\ B. R. Pickenheim \\ A. L. Billings \\ N. E. Bibler
}

November 2008

Savannah River National Laboratory

Savannah River Nuclear Solutions

Aiken, SC 29808

Prepared for the U.S. Department of Energy Under Contract Number DE-AC09-08SR22470

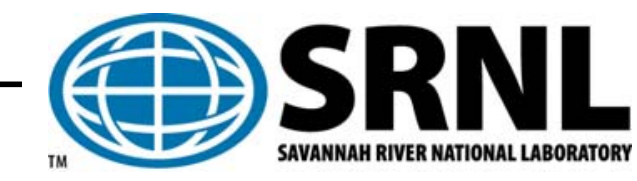




\section{DISCLAIMER}

This work was prepared under an agreement with and funded by the U.S. Government. Neither the U. S. Government or its employees, nor any of its contractors, subcontractors or their employees, makes any express or implied:

1. warranty or assumes any legal liability for the accuracy, completeness, or for the use or results of such use of any information, product, or process disclosed; or

2. representation that such use or results of such use would not infringe privately owned rights; or

3. endorsement or recommendation of any specifically identified commercial product, process, or service.

Any views and opinions of authors expressed in this work do not necessarily state or reflect those of the United States Government, or its contractors, or subcontractors.

Printed in the United States of America

Prepared for

U.S. Department of Energy 
Key Words:

DWPF

Qualification

Retention:

Permanent

\title{
SLUDGE WASHING AND DEMONSTRATION OF THE DWPF FLOWSHEET IN THE SRNL SHIELDED CELLS FOR SLUDGE BATCH 5 QUALIFICATION
}

\author{
J. M. Pareizs \\ C. J. Bannochie \\ D. R. Click \\ D. P. Lambert \\ M. E. Stone \\ B. R. Pickenheim \\ A. L. Billings \\ N. E. Bibler
}

November 2008

Savannah River National Laboratory

Savannah River Nuclear Solutions

Aiken, SC 29808

Prepared for the U.S. Department of Energy Under Contract Number DE-AC09-08SR22470

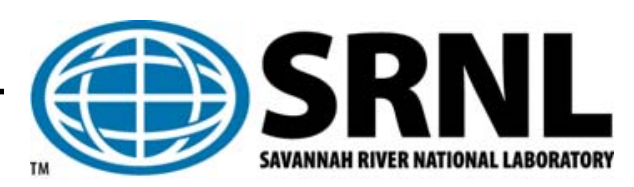




\section{REVIEWS AND APPROVALS}

\section{AUTHORS:}

J. M. Pareizs, Process Engineering Technology

Date

C. J. Bannochie, Process Engineering Technology

Date

D. R. Click, Analytical Development

Date

D. P. Lambert, Process Engineering Technology

Date

M. E. Stone, Process Engineering Technology

Date

B. R. Pickenheim, Process Engineering Technology

Date

A. L. Billings, Process Engineering Technology

Date

N. E. Bibler, Process Engineering Technology

Date

\section{TECHNICAL REVIEWERS:}

S. H. Reboul, Process Engineering Technology

Date

D. K. Peeler, Process Engineering Technology

Date

\section{APPROVERS:}

C. C. Herman, Manager, Process Engineering Technology

Date

J. C. Griffin, Manager, Research Programs, E\&CPT

Date

J. E. Occhipinti, Manager, Waste Solidification Engineering

Date 


\section{TABLE OF CONTENTS}

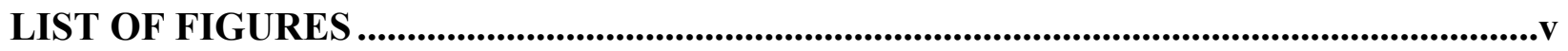

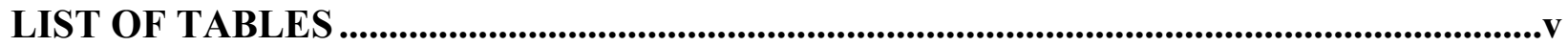

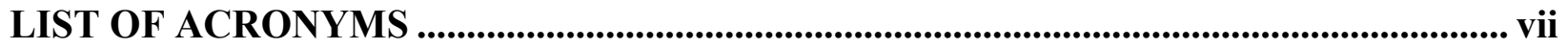

EXECUTIVE SUMMARY ...................................................................................................1

1.0 INTRODUCTION AND BACKGROUND.........................................................................3

2.0 TANK 51 SLUDGE WASHING ........................................................................................4

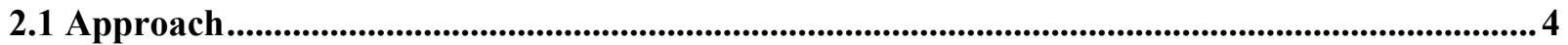

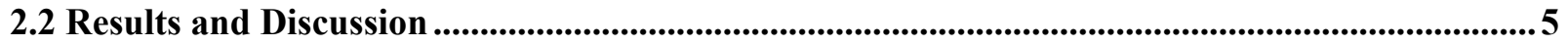

3.0 SEMIVOLATILE AND VOLATILE ANALYSIS OF THE SRNL WASHED

SLUDGE BATCH 5 QUALIFICATION SAMPLE .................................................11

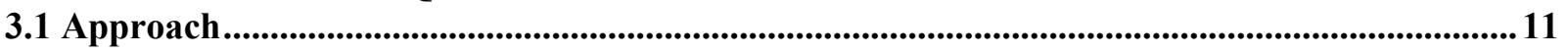

3.1.1 Semivolatile Organic Compound Analysis Experimental..................................... 11

3.1.2 Volatile Organic Compound Analysis Experimental ........................................... 11

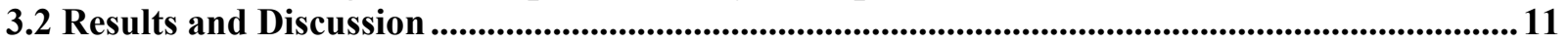

3.2.1 Semivolatile Organic Compound Analysis Discussion ......................................... 11

3.2.2 Volatile Organic Compound Analysis Discussion................................................ 12

4.0 CHEMICAL PROCESS CELL SIMULATIONS ....................................................13

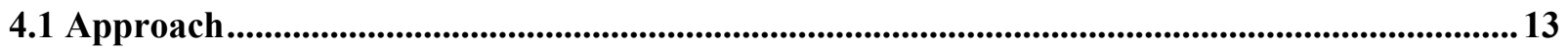

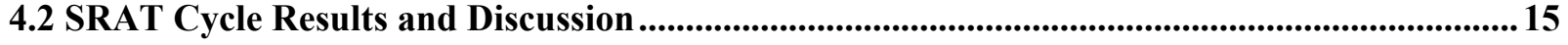

4.2.1 SRAT Receipt Acid Addition Calculations.................................................................. 15

4.2.2 SRAT Product Characterization Results and SRAT Cycle Observations ............ 17

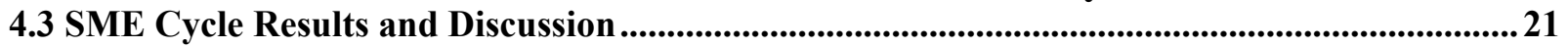

4.4 SC-6 CPC Processing Anion Destruction and Conversion..................................................24

5.0 GLASS FABRICATION AND PCT ...................................................................................26

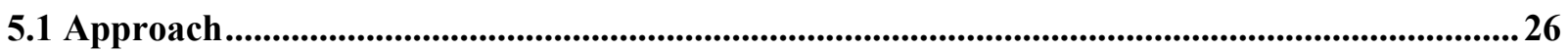

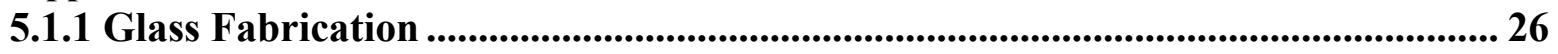

5.1.2 Glass Dissolution Methods and Analyses......................................................... 26

5.1.3 Standard ASTM 1285 Leach Test Procedure .................................................... 26

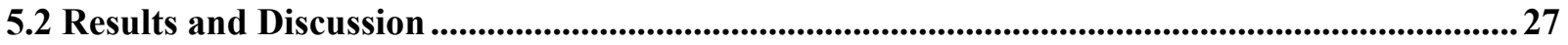

5.2.1 Measured Composition of the SB5 Qualification Glass ......................................... 27

5.2.2 Processability of the SB5 Qualification Glass .................................................... 29

5.2.3 Estimated Waste Loading for the SB5 Qualification Glass .................................... 32

5.2.4 Results of the ASTM 1285 Leach Test (Product Consistency Test)....................... 32

6.0 Rheology .................................................................................................................................35

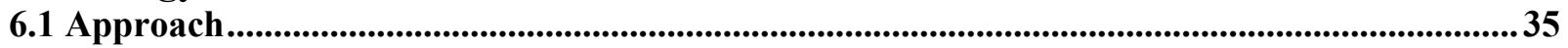

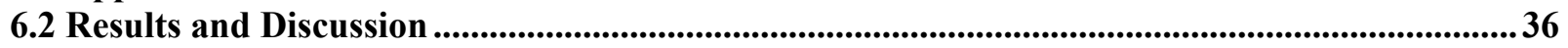

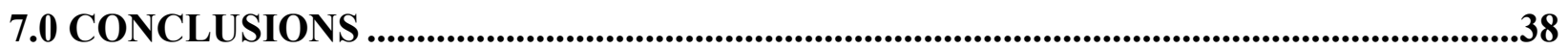

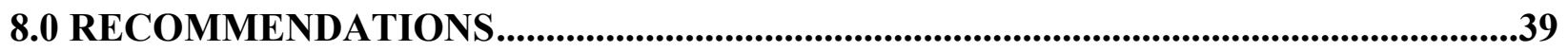

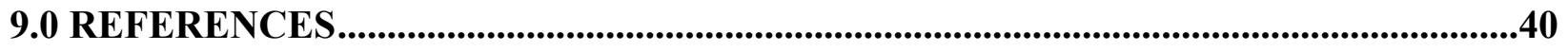

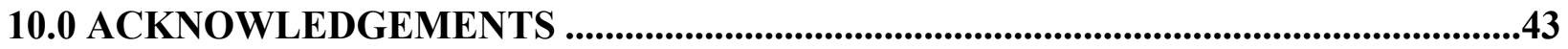

Appendix A. Settling Data during SB5 Qualification Washing................................................44

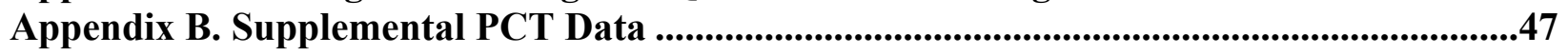

Appendix C. Rheological Charts and Flow Curves ..............................................................49

Appendix D. SC-6 Processing Mass Balance and Anion Conversion/Destruction

Calculations ..............................................................................................................................51 
SRNS-STI-2008-00111, REVISION 0

Appendix E. Calculation of Soluble and Insoluble Aluminum and Sodium based on 100

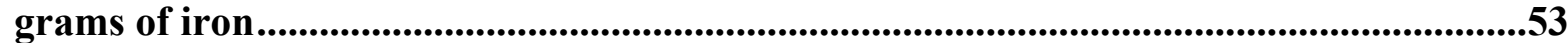




\section{LIST OF FIGURES}

Figure 1. Sludge Settling During SRNL Washing of Tank 51 Qualification Sample...........10

Figure 2. Schematic of SRAT Equipment Set-Up.........................................................14

Figure 3. SC-6 DWPF Scale SRAT Cycle Gas Generation ......................................................19

Figure 4. SC-6 DWPF Scale SME Cycle Gas Generation .......................................................24

Figure 5. Predictability of the PCT Response of the SB5 Qualification Glass.......................31

Figure C-1. Tank 51 SB5 Qual Sample, As-Received, May 2007, Flow Curve....................49

Figure C-2. Tank 51, SB5 Qual Sample SRNL Washed and Decanted to $15.9 \mathrm{wt} \%$

Total Solids, Flow Curves.

Figure C-3. Tank 51, SB5 Qual Sample SRNL Washed and Decanted to $17.1 \mathrm{wt} \%$

Total Solids (SC-6 SRAT Receipt), Flow Curves ........................................................49

Figure C-4. SRNL SC-6 SRAT Product at 26.5 wt\% Total Solids, Flow Curves.................50

Figure C-5. SRNL SC-6 SRAT Product at 20 wt\% Total Solids, Flow Curves .....................50

Figure C-6. SRNL SC-6 SME Product, Flow Curves................................................................50

\section{LIST OF TABLES}

Table 1. Tank Farm Sludge Batch 5 Planned Washing Amount ...........................................4

Table 2. SRNL Washing Analytical Results .............................................................................6

Table 3. Elements Present at $>0.1$ Wt\% of Total Solids in the As-Received Tank 51

Sludge Batch 5 Qualification Sample ..........................................................................................7

Table 4. Concentrations of Elements in Total Solids and Calcined Solids of the SC-6

SRAT Receipt (Wash F Add'l) .......................................................................................7

Table 5. Elements Present at $>1$ Wt\% of Total Solids in the As-Received Tank 51

Sludge Batch 5 Qualification Sample .............................................................................8

Table 6. Aluminum and Sodium Solubility, Percent Removed During Washing, and

Mass Insoluble based on $100 \mathrm{~g}$ Fe........................................................................................9

Table 7. Anions, Total Inorganic Carbon, Mercury, and Base Equivalents in the SC-6

SRAT Receipt .................................................................................................................9

Table 8. Summary of CPC Processing ..........................................................................................13

Table 9. Acid Calculation Inputs for the Tank 51 Sludge Batch 5 Qualification (SC-6)

CPC Simulation

Table 10. SRAT Cycle Acid Requirements...................................................................17

Table 11. Weight Percent Solids and Density of the SC-6 SRAT Product ...........................17

Table 12. Anions, Total Inorganic Carbon, Mercury, and pH of the SC-6 SRAT

Product ................................................................................................................................................17

Table 13. Concentrations of Elements in the SC-6 SRAT Product.....................................18

Table 14. Maximum Observed Hydrogen, Carbon Dioxide, and Nitrous Oxide Volume

Percent and DWPF Scale Generation Rates during the SC-6 SRAT Cycle .....................18

Table 15. Elements in SC-6 SRAT Receipt and SRAT Product Supernatants and

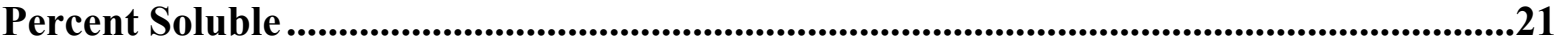

Table 16. Weight Percent Solids, pH, and Density of the SC-6 SME Product.......................22

Table 17. SC-6 SME Product Slurry Anion Concentrations ...............................................23 
Table 18. SC-6 SME Product Carbon Analysis .23

Table 19. Maximum Observed Hydrogen, Carbon Dioxide, and Nitrous Oxide Volume Percent and DWPF Scale Generation Rates during the SC-6 SME Cycle .23

Table 20. SC-6 Assumed and Measured Anion Destruction and Conversion with Comparison to Applicable Simulant Run .25

Table 21. Average of Elemental Concentrations Measured in SB5 Qualification Glass by ICP-AES

Table 22. Average Concentrations of Oxides with Concentrations $\geq 0.1$ Weight Percent in SB5 Qualification Glass Measured by ICP-AES .28

Table 23. Measured SB5 Qualification Glass Composition for Input into PCCS .29

Table 24. PCCS Results for SB5 Qualification Glass ....................................................................31

Table 25. Average PCT Results for EA and the SB5 Qualification Glasses............................33

Table 26. PCT Results for Measured Radionuclides in SB5 Qualification Glass....................34

Table 27. MV I and MV II Rotor Specifications and Flow Curve Program..........................36

Table 28. Rheology Measurements of Sludges, SRAT Products, and SME Products...........37

Table B-1. Parameters Prescribed in ASTM-1285-02 Procedure for Successful

Performance of a Product Consistency Test using Test Method A

Table B-2. Requirements Prescribed in ASTM-1285-02 Procedure for Analytical

Results of Multielement Standard and Blanks in Product Consistency Test using

Test Method A 
SRNS-STI-2008-00111, REVISION 0

\section{LIST OF ACRONYMS}

ACTL

$\mathrm{AD}$

ARM

ASP

CPC

CS

DWPF

FAVC

GC

GC/MS

$\mathrm{HM}$

IC

ICP-AES

ICP-MS

IS

LIMS

LWO

MAR

MWWT

NIST

NL

PCCS

PCT

PMP

PSAL

QA

REDOX

RSD

SB4

SB5

SME

SMECT

SRAT

SRNL

SRS

SS

SVOA

SVOC

TIC

TOC

TS

TTQAP

TTR

VOA

VOC

WAPS

WL
Aiken County Technologies Laboratory

Analytical Development

Approved Reference Material

Analytical Study Plan

Chemical Process Cell

Calcined Solids

Defense Waste Processing Facility

Formic Acid Vent Condenser

Gas Chromatograph

Gas Chromatograph - Mass Spectrometer

H-Modified

Ion Chromatography

Inductively Coupled Plasma - Atomic Emission Spectroscopy

Inductively Coupled Plasma - Mass Spectroscopy

Insoluble Solids

Laboratory Information Management System

Liquid Waste Organization

Measurement Acceptability Region

Mercury Water Wash Tank

National Institute of Standards and Testing

Normalized PCT Release

Product Composition Control System

Product Consistency Test

Polymethyl propylene

Process Science Analytical Laboratory

Quality Assurance

REDuction / OXidation potential

Relative Standard Deviation

Sludge Batch 4

Sludge Batch 5

Slurry Mix Evaporator

Slurry Mix Evaporator Condensate Tank

Sludge Receipt and Adjustment Tank

Savannah River National Laboratory

Savannah River Site

Soluble Solids

Semivolatile Organic Analysis

Semivolatile Organic Compound

Total Inorganic Carbon

Total Organic Carbon

Total Solids

Task Technical and Quality Assurance Plan

Technical Task Request

Volatile Organic Analysis

Volatile Organic Compound

Waste Acceptance Product Specification

Waste Loading 


\section{EXECUTIVE SUMMARY}

Sludge Batch 5 (SB5) is predominantly a combination of H-modified (HM) sludge from Tank 11 that underwent aluminum dissolution in late 2007 to reduce the total mass of sludge solids and aluminum being fed to the Defense Waste Processing Facility (DWPF) and Purex sludge transferred from Tank 7. Following aluminum dissolution and the addition of Tank 7 sludge and excess Pu to Tank 51, Liquid Waste Operations (LWO) provided the Savannah River National Laboratory (SRNL) a 3-L sample of Tank 51 sludge for SB5 qualification. SB5 qualification included washing the sample per LWO plans/projections (including the addition of a $\mathrm{Pu} / \mathrm{Be}$ stream from $\mathrm{H}$ Canyon), DWPF Chemical Process Cell (CPC) simulations, waste glass fabrication (vitrification), and waste glass chemical durability evaluation.

Sludge Washing

SRNL washed the Tank 51 SB5 qualification sample per LWO plans/projections of April 2008 with the reduction of one wash/decant cycle. Washing included the addition of a $\mathrm{Pu} / \mathrm{Be}$ stream from $\mathrm{H}$ Canyon and supernatant from Tank 40. During washing, settling and decanting behavior were similar to previous sludge batches (i.e., some settling periods were slower while others were faster but overall were not predictable). SRNL was able to produce a sludge at $11.2 \mathrm{wt} \%$ insoluble solids with rheology acceptable for DWPF processing.

\section{DWPF CPC Simulations}

The SRNL washed Tank 51 SB5 qualification sample was used in a Sludge Receipt and Adjustment Tank (SRAT) cycle and a Slurry Mix Evaporator (SME) cycle. The objectives of these simulations were accomplished with an acid stoichiometry of 130\%: nitrite was destroyed; mercury was removed to below $0.45 \mathrm{wt} \%$ total solids in the SRAT product; and DWPF hydrogen generation rates were not exceeded. Peak offgas generation rates during SRAT processing were $0.495 \mathrm{lb} / \mathrm{h}$ for hydrogen, $323 \mathrm{lb} / \mathrm{h}$ for carbon dioxide, and $66.8 \mathrm{lb} / \mathrm{h}$ for nitrous oxide when scaled to a DWPF 6,000 gallon SRAT receipt volume. During SME processing, peak offgas generation rates were $0.148 \mathrm{lb} / \mathrm{h}$ for hydrogen, $45.0 \mathrm{lb} / \mathrm{h}$ for carbon dioxide, and $4.52 \mathrm{lb} / \mathrm{h}$ for nitrous oxide. The Total Organic Carbon content of the SME product slurry was $9,920 \mathrm{mg} / \mathrm{kg}$, which is much less than the DWPF melter flammability limit. There were no issues with heat transfer, water removal, or sample mixing in the SRNL apparatus.

During the SRAT cycle, excessive foaming was observed during formic acid addition and during boiling. $100 \mathrm{ppm}$ additions of antifoam were added nearly hourly during boiling to control foaming. It is not clear if foaming was a property of the sludge or due to inferior antifoam based on recent DWPF experience. An adequate assessment of foaming could not be made during the SME cycle because of the small amount of sample. However, the SME slurry was maintained below the upper window of the vessel insulation so foaming was not excessive. A $100 \mathrm{ppm}$ addition of antifoam was added with each decon water and Frit 418/water addition to ensure foaming would not be an issue.

Waste Glass Fabrication and Chemical Durability

Glass was fabricated from a subsample of SME product. The targeted waste loading was 34 wt $\%$ waste oxides. The glass was acceptable with respect to chemical durability as measured by the Product Consistency Test (PCT). The PCT response was also predictable by the current 
durability models of the DWPF Product Composition Control System (PCCS). Finally, the normalized PCT responses for several radionuclides were measured and found to be less than the normalized PCT responses for $\mathrm{B}, \mathrm{Na}$, and $\mathrm{Li}$.

\section{Rheology}

The rheology (yield stress and consistency) of samples throughout processing (As-received, SRNL-washed, SRAT and SME products) were measured. These measurements showed that the washed Tank 51 material could be concentrated up to $11.2 \mathrm{wt} \%$ insoluble solids. The SRAT product at $26.5 \mathrm{wt} \%$ total solids exceeded the DWPF limit for SRAT product yield stress. A sample adjusted to $20 \mathrm{wt} \%$ total solids had acceptable rheological properties. The SME product yield stress only slightly exceeded DWPF limits at a measured wt $\%$ total solids of 48.8 . It is anticipated that rheology would be acceptable at the target of $45 \mathrm{wt} \%$ total solids. Also, DWPF has processed SME products with equivalent yield stress and consistency to the higher solids sample.

\section{Recommendations}

Based on these simulations and the associated SB5 simulant runs with the blend projected to be processed as SB5, SRNL recommends the following for Sludge Batch 5 processing:

- A final washed Tank 51 concentration of no more than $11.2 \mathrm{wt} \%$ insoluble solids

- A SRAT cycle acid stoichiometry of $130 \%$

- SRAT product solids concentration target of $20 \mathrm{wt} \%$ total solids

- SRAT boiling time (dewater plus reflux) of 18 hours at 5,000 lb/hr steam $(90,000 \mathrm{lb}$ of steam total) to ensure $\mathrm{Hg}$ reduction

- SME product concentration of $45 \mathrm{wt} \%$ total solids

- Glass waste loading of 34 wt \% waste oxides using Frit 418 (if the Pu limit does not cause a lower value to be targeted)

These are initial recommendations and could be adjusted based on DWPF processing of the blend of SB5 with the heel of SB4 since blend studies were not performed with radioactive sludge and the heel is not considered in SRNL studies. It is also recommended that foaming during SB5 processing be carefully observed. Without further testing to evaluate the cause of foaming (a sludge characteristic or inferior antifoam), a specific antifoam addition strategy cannot be recommended at this time. SRNL recommends antifoam testing using a sample of SB5 - Tank 51 in the first quarter of fiscal year 2009 to provide a reasonable antifoam strategy. However, the customer has requested SRNL to evaluate antifoam using a Tank 40 sample (following the SB5 transfer from Tank 51 to Tank 40) early in the second quarter of fiscal year 2009.

As part of SRNL's FY09 testing to support DWPF processing, further chemical and physical characterization of radioactive slurries will be performed to try to better understand the causes for the increased foaminess and yield stress of radioactive sludges compared to the simulants fabricated for testing. SRNL simulant testing will also focus on trying to better represent the properties of aluminum dissolved sludge since aluminum dissolution is anticipated to be performed on most of the HM sludge remaining to be processed through DWPF. 


\subsection{INTRODUCTION AND BACKGROUND}

Sludge Batch 5 (SB5) is predominantly a combination of H-modified (HM) sludge from Tank 11 that underwent aluminum dissolution in late 2007 to reduce the total mass of sludge solids and aluminum being fed to the Defense Waste Processing Facility (DWPF) and Purex sludge transferred from Tank 7. Following aluminum dissolution, the addition of Tank 7 sludge and excess Pu to Tank 51, Liquid Waste Operations (LWO) provided the Savannah River National Laboratory (SRNL) a 3-L sample of Tank 51 sludge for SB5 qualification. ${ }^{1}$ SB5 qualification included washing the sample per LWO plans/projections (including the addition of a $\mathrm{Pu} / \mathrm{Be}$ stream from $\mathrm{H}$ Canyon), DWPF Chemical Process Cell (CPC) simulations, waste glass fabrication (vitrification), and waste glass chemical durability evaluation.

This report documents:

- The washing (addition of water to dilute the sludge supernatant) and concentration (decanting of supernatant) of the Tank 51 qualification sample to adjust sodium content and weight percent insoluble solids to Tank Farm projections.

- The performance of a DWPF CPC simulation using the washed Tank 51 sample. This includes a Sludge Receipt and Adjustment Tank (SRAT) cycle, where acid is added to the sludge to destroy nitrite and remove mercury, and a Slurry Mix Evaporator (SME) cycle, where glass frit is added to the sludge in preparation for vitrification. The SME cycle also included replication of five canister decontamination additions and concentrations. Processing parameters for the CPC processing were based on work with a non radioactive simulant. $^{2}$

- Vitrification of a portion of the SME product and Product Consistency Test (PCT) evaluation of the resulting glass.

- Rheology measurements of the initial slurry samples and samples after each phase of CPC processing.

This work is controlled by a Task Technical and Quality Assurance Plan (TTQAP) ${ }^{3}$, and analyses are guided by an Analytical Study Plan ${ }^{4}$. This work is Technical Baseline Research and Development (R\&D) for the DWPF. 


\subsection{TANK 51 SLUDGE WASHING}

\subsection{APPROACH}

The Sludge Batch 5 qualification sample (HTF-51-08-42) was transferred from a Tank Farm sample container to a 1-gallon wide mouth glass bottle for washing. A centimeter scale was affixed to the bottle, and a correlation between volume and height was made to facilitate sludge and slurry volume determination.

Decants and additions to the sample were made based on the most up to date Tank Farm washing strategy (see Table 1). The strategy was changed several times during SRNL's preparation; thus, several spreadsheets were used. Tank Farm volumes were scaled to SRNL volumes. For the SRNL washing, deionized water was used for wash water. $\mathrm{A} \mathrm{Pu} / \mathrm{Be}$ solution from $\mathrm{H}$ Canyon ${ }^{5}$ was combined with reagent grade $50 \mathrm{wt} \%$ sodium hydroxide solution to produce a slurry with 1.2 $\mathrm{M}$ excess hydroxide to simulate $\mathrm{H}$ Canyon operations prior to discharge to the Tank Farm. This resulting slurry was added to the qualification sample after Decant $\mathrm{C}$ to be consistent with the Tank Farm addition. Supernatant from the Sludge Batch 4 Waste Acceptance Product Specification (WAPS) sample ${ }^{6}$ diluted with deionized water to match current Tank 40 conditions was used for the Tank 40 supernatant. Reagent grade sodium nitrite and deionized water were used for the $40 \mathrm{wt} \%$ sodium nitrite solution.

Table 1. Tank Farm Sludge Batch 5 Planned Washing Amount

\begin{tabular}{|c|c|}
\hline Description of Step & Amount (gal) \\
\hline Decant A & 120,732 \\
\hline Wash B using Tank 40 supernatant & $100,000^{\S}$ \\
\hline Decant B & $149,456^{\dagger}$ \\
\hline Wash C using water & $165,198^{\dagger}$ \\
\hline Decant $\mathrm{C}$ & $150,000^{\dagger}$ \\
\hline Addition of $\mathrm{Pu} / \mathrm{Be}$ stream from $\mathrm{H}$ Canyon & $5,877 \mathrm{Pu} / \mathrm{Be}^{\dagger}$ \\
\hline $\begin{array}{l}\text { Wash D using sodium nitrite, Tank } 40 \\
\text { supernatant, and water }\end{array}$ & $\begin{array}{c}16,80240 \mathrm{wt} \% \mathrm{NaNO}_{2} \text { solution } \\
100,000 \text { Tank } 40 \text { supernatant } \\
27,321 \text { water } \\
\end{array}$ \\
\hline Decant D & $150,000^{*}$ \\
\hline Wash E using water & $150,000^{*}$ \\
\hline Decant E & $150,000^{*}$ \\
\hline Wash F using water & $150,000^{*}$ \\
\hline Decant F & $150,000^{*}$ \\
\hline \multicolumn{2}{|c|}{$\begin{array}{l}\text { * Actual decant amount, taken from "SB4-5_041608_50\% retention.xls". } \\
\text { " From "SB4-5_041608_50\% retention.xls". } \\
\text { "From "SB4-5_042208_50\% retention.xls". } \\
\text { F From "SB4-5_042808_50\% retention_40 Decant } 2 \text { for } 51 \text { Wash D_20cpm.xls". } \\
\text { Note. This table was published previously in Reference } 7\end{array}$} \\
\hline
\end{tabular}

Following each SRNL decant, except Decant C, a slurry sample was collected for analysis. Instead of sampling after Decant $\mathrm{C}$, a sample was taken following the addition of the $\mathrm{Pu} / \mathrm{Be}$ material. Weight percent total solids and density measurements were performed on these slurry 
samples. Measurements of elemental and anion content, density, and weight percent dissolved solids were performed on the decants (supernatants). Weight percent insoluble solids were calculated from the applicable total and dissolved solids measurements. Note that the Tank Farm plans in April 2008 included an additional wash (Wash/Decant Z). However, following Wash F, sodium in the supernatant was near the Wash Z target of 1.0 M. Therefore, SRNL recommended and LWO concurred on the elimination of Wash Z.

Sludge level was periodically recorded during settling after wash water additions to provide a semi-qualitative assessment of settling behavior throughout washing.

\subsection{RESULTS AND DISCUSSION}

Analytical results of the as-received Tank 51 sample (post wash A) and samples taken during washing are presented in Table 2. For the final decant (Decant F), SRNL removed as much supernatant as possible. The resulting volume was equivalent to a Tank Farm Decant $F$ of 195,000 gal. A smaller sample to represent a decant of 150,000 was also prepared. The sample representing the original 150,000 gallon Decant F is designated as Wash F Std (Standard). The material representing the decant of 195,000 gallons is designated as Wash F Add'l (Additional decant). Results included in the table are weight percent solids, density, and supernatant anions, sodium, aluminum, and elemental sulfur. The rheology of Wash F Std and Wash F Add'l was measured (see Section 6.0). Since the rheology of the higher insoluble solids sample (Wash F Add'l) was acceptable for DWPF processing, Wash F Add'l was used as the SB5 SRAT receipt material and was further characterized. Note that the Wash F Add'l slurry is designated as SC-6 (Shielded Cells DWPF simulation number six) SRAT receipt for DWPF CPC processing. .

Table 2 includes a row showing the supernatant (soluble) aluminum to sulfur ratio. As shown in the table, the ratio drops from thirteen to nine as the sample is washed. This may indicate aluminum precipitation as washing progressed since a constant ratio would indicate soluble aluminum and sulfur being removed in the same proportions. Note that aluminum and sulfur cannot be compared to other soluble species (sodium, nitrite, nitrate) since these species were added during the Wash/Decant $\mathrm{C}+$ cycle. 
Table 2. SRNL Washing Analytical Results

\begin{tabular}{|c|c|c|c|c|c|c|c|c|}
\hline & $\begin{array}{l}\text { As- } \\
\text { Rcv'd }\end{array}$ & $\begin{array}{c}\text { After } \\
\text { Decant } \\
\text { A }\end{array}$ & $\begin{array}{c}\text { After } \\
\text { Wash / } \\
\text { Decant } \\
\text { B }\end{array}$ & $\begin{array}{c}\text { After } \\
\text { Wash / } \\
\text { Decant } \\
\mathrm{C}+\mathrm{Pu} / \\
\mathrm{Be}^{*}\end{array}$ & Wash D & Wash E & $\begin{array}{l}\text { Wash F } \\
\text { Std }\end{array}$ & $\begin{array}{l}\text { Wash F } \\
\text { Add'l }\end{array}$ \\
\hline $\begin{array}{l}\text { Supernatant Density } \\
(\mathrm{kg} / \mathrm{L})\end{array}$ & 1.19 & $--^{\dagger}$ & 1.15 & 1.10 & 1.10 & 1.07 & 1.06 & $-{ }^{\dagger}$ \\
\hline Slurry Density $(\mathrm{kg} / \mathrm{L})$ & 1.24 & NM & NM & $\mathrm{NM}$ & NM & NM & 1.14 & 1.14 \\
\hline $\begin{array}{l}\text { Total Solids ( } \mathrm{wt}^{\%} \% \text { of } \\
\text { slurry) }\end{array}$ & 23.6 & 24.6 & 24.1 & 19.5 & 19.2 & 17.0 & 15.9 & 17.1 \\
\hline $\begin{array}{l}\text { Dissolved Solids (wt } \% \text { of } \\
\text { supernatant) }\end{array}$ & 19.3 & $--^{\dagger}$ & 16.9 & 12.2 & 11.0 & 8.09 & 6.64 & $-\dagger$ \\
\hline $\begin{array}{l}\text { Insoluble Solids (wt\% of } \\
\text { slurry) }\end{array}$ & 5.31 & 6.56 & 8.63 & 8.25 & 9.25 & 9.71 & 9.86 & 11.2 \\
\hline $\begin{array}{l}\text { Soluble Solids (wt } \% \text { of } \\
\text { slurry) }\end{array}$ & 18.3 & 18.1 & 15.5 & 11.2 & 9.99 & 7.31 & 5.99 & 5.90 \\
\hline $\begin{array}{l}\text { Calcined Solids (wt } \% \text { of } \\
\text { slurry) }\end{array}$ & 15.4 & NM & NM & NM & 14.5 & NM & NM & 14.0 \\
\hline Fluoride $(\mathrm{M})$ & $<0.05$ & $--^{\dagger}$ & $<0.05$ & $<0.05$ & $<0.05$ & $<0.03$ & $<0.03$ & $--^{\dagger}$ \\
\hline Formate $(\mathrm{M})$ & $<0.02$ & $-{ }^{\dagger}$ & $<0.02$ & $<0.02$ & $<0.02$ & $<0.01$ & $<0.01$ & $--^{\dagger}$ \\
\hline Chloride (M) & $<0.03$ & $-\dagger$ & $<0.03$ & $<0.03$ & $<0.03$ & $<0.01$ & $<0.01$ & $-\dagger^{\dagger}$ \\
\hline Nitrite $(\mathrm{M})$ & 0.41 & $-^{\dagger}$ & 0.35 & 0.24 & 0.48 & 0.31 & 0.22 & $--^{\dagger}$ \\
\hline Nitrate $(\mathrm{M})$ & 0.41 & $-\dagger$ & 0.32 & 0.30 & 0.23 & 0.17 & 0.13 & $--^{\dagger}$ \\
\hline Phosphate (M) & $<0.01$ & $-\dagger$ & $<0.01$ & $<0.01$ & $<0.01$ & $<0.005$ & $<0.005$ & $--^{\dagger}$ \\
\hline Sulfate (M) & 0.025 & $--^{\dagger}$ & 0.020 & 0.015 & 0.013 & 0.010 & 0.0079 & $--^{\dagger}$ \\
\hline Oxalate (M) & $<0.01$ & $-\dagger^{\dagger}$ & $<0.01$ & $<0.01$ & $<0.01$ & $<0.006$ & $<0.006$ & $-\dagger^{\dagger}$ \\
\hline $\mathrm{Na}(\mathrm{M})$ & 3.94 & $-{ }^{\dagger}$ & 3.49 & 2.48 & 2.17 & 1.58 & 1.14 & $-{ }^{\dagger}$ \\
\hline $\mathrm{Al}(\mathrm{M})$ & 0.32 & $-^{\dagger}$ & 0.26 & 0.18 & 0.13 & 0.10 & 0.073 & $--^{\dagger}$ \\
\hline $\mathrm{S}(\mathrm{M})$ & 0.025 & $--^{\dagger}$ & 0.024 & 0.017 & 0.014 & 0.011 & 00078 & $--^{\dagger}$ \\
\hline Ratio of Al:S & 13 & NA & 11 & 11 & 9 & 9 & 9 & NA \\
\hline
\end{tabular}

Following Wash/Decant $\mathrm{C}$ (which included addition of sodium nitrite and the use of Tank 40 supernatant), a Pu/Be mixture was added to the Tank 51 sample. These results reflect that addition.

$-\dagger$ Note that the supernatant following Decant A ("After Decant A") is identical to the as-received ("As-Rcv'd") supernatant. The post Wash F supernatants (Wash F Std and Wash F Add'l) are identical.

Table 3 provides the results of elemental analysis of the total solids of the as-received qualification sample. ${ }^{8}$ Only major elements $(>0.1 \mathrm{wt} \%$ of the total solids) are listed. 
Table 3. Elements Present at $>0.1$ Wt $\%$ of Total Solids in the As-Received Tank 51 Sludge Batch 5 Qualification Sample

\begin{tabular}{|c|c|c|c|}
\hline Element & $\begin{array}{c}\text { Wt\% of } \\
\text { Total Solids) }\end{array}$ & Element & $\begin{array}{c}\text { Wt\% of Total } \\
\text { Solids) }\end{array}$ \\
\hline $\mathrm{Al}$ & 6.18 & $\mathrm{Mn}$ & 1.62 \\
\hline $\mathrm{Ca}$ & 0.578 & $\mathrm{Na}$ & 32.0 \\
\hline $\mathrm{Fe}$ & 6.91 & $\mathrm{Ni}$ & 0.991 \\
\hline $\mathrm{Hg}$ & 1.23 & $\mathrm{~S}$ & $<1.3$ \\
\hline $\mathrm{K}$ & $<0.50$ & $\mathrm{Si}$ & 0.371 \\
\hline $\mathrm{Mg}$ & 0.259 & $\mathrm{U}$ & 2.38 \\
\hline
\end{tabular}

Table 4 provides the results of elemental analysis of the SRNL washed Tank 51 qualification sample, Wash F Add'l (SC-6 SRAT receipt). ${ }^{9}$ Major elements are included along with those specifically requested by DWPF ${ }^{1}$ and the noble metals. A column with the elemental results on a calcined solids basis is also included for use in projecting the final glass composition.

Table 4. Concentrations of Elements in Total Solids and Calcined Solids of the SC-6 SRAT Receipt (Wash F Add'l)

\begin{tabular}{|c|c|c|c|c|c|}
\hline Element & $\begin{array}{c}\text { Wt\% of } \\
\text { Total } \\
\text { Solids }\end{array}$ & $\begin{array}{c}\text { Wt\% of } \\
\text { Calcined } \\
\text { Solids * }\end{array}$ & Element & $\begin{array}{c}\text { Wt\% of } \\
\text { Total } \\
\text { Solids }\end{array}$ & $\begin{array}{c}\text { Wt\% of } \\
\text { Calcined } \\
\text { Solids }\end{array}$ \\
\hline $\mathrm{Al}$ & 8.91 & 10.9 & $\mathrm{Ni}$ & 2.34 & 2.87 \\
\hline $\mathrm{As}$ & $<0.0027$ & $<0.0033$ & $\mathrm{P}$ & 0.210 & 0.257 \\
\hline $\mathrm{Ba}$ & 0.106 & 0.130 & $\mathrm{~Pb}$ & 0.0364 & 0.0446 \\
\hline $\mathrm{Be}$ & $<0.00031$ & $<0.00038$ & $\mathrm{~S}$ & $<0.31$ & $<0.38$ \\
\hline $\mathrm{Ca}$ & 1.31 & 1.60 & $\mathrm{Sb}$ & $<0.11$ & $<0.13$ \\
\hline $\mathrm{Cd}$ & 0.0458 & 0.0561 & $\mathrm{Se}$ & $<0.0054$ & $<0.0066$ \\
\hline $\mathrm{Co}$ & 0.00337 & 0.00413 & $\mathrm{Si}$ & 0.923 & 1.13 \\
\hline $\mathrm{Cr}$ & 0.0467 & 0.0572 & $\mathrm{Ti}$ & 0.0200 & 0.0245 \\
\hline $\mathrm{Cu}$ & 0.0624 & 0.0764 & $\mathrm{U}$ & 5.33 & 6.53 \\
\hline $\mathrm{Fe}$ & 16.3 & 20.0 & $\mathrm{~V}$ & $<0.11$ & $<0.13$ \\
\hline $\mathrm{Hg}$ & 2.22 & $\mathrm{NC}$ & \multicolumn{3}{|c|}{$\mathrm{Noble} \mathrm{Metals}$} \\
\hline $\mathrm{K}$ & $<0.12$ & $<0.15$ & $\mathrm{Ru}$ & 0.110 & $\mathrm{NC}^{\dagger}$ \\
\hline $\mathrm{Mg}$ & 0.604 & 0.740 & $\mathrm{Rh}$ & 0.0250 & $\mathrm{NC}^{\dagger}$ \\
\hline $\mathrm{Mn}$ & 3.66 & 4.48 & $\mathrm{Pd}$ & 0.00403 & $\mathrm{NC}^{\dagger}$ \\
\hline $\mathrm{Na}$ & 15.2 & 18.6 & $\mathrm{Ag}$ & 0.0135 & $\mathrm{NC}^{\dagger}$ \\
\hline
\end{tabular}

${ }^{*}$ Weight percent calcined solids was calculated by multiplying the elemental weight percent total solids by the ratio of slurry weight percent total solids and slurry weight percent calcined solids.

${ }^{\dagger} \mathrm{NC}$-not calculated. $\mathrm{Wt} \%$ calcined solids is primarily used for glass composition projections. Much of the Hg is removed in the SRAT cycle with the remainder volatilized in the vitrification process. The noble metals are present in the final glass, but they do not contribute significantly to the final glass composition. 
A comparison between the elemental content of the total solids in the as-received Tank 51 sample and the washed sample is shown in Table 5 for the major elements (greater than 1\% in the as-received material). As expected, the concentration of the primary soluble element, sodium, dropped significantly due to washing. Included in the table is a column with the ratio of the SRNL-washed sludge elementals to the as-received elementals. During washing, soluble solids are removed, and insoluble elements are concentrated relative to total solids. A comparison of ratios to the iron ratio, the primary insoluble element, and sodium ratio, the primary soluble element, can give a qualitative indication of an element's solubility. Insoluble elements should have ratios similar to that for iron (2.3 to 2.4). Partially soluble elements would have ratios smaller than iron but greater than sodium. For example, aluminum and mercury have ratios less than two, showing they are partially soluble, and a portion of each was removed during washing.

Table 5. Elements Present at $>1$ Wt\% of Total Solids in the As-Received Tank 51 Sludge Batch 5 Qualification Sample

\begin{tabular}{|l|c|c|c|}
\hline Element & $\begin{array}{c}\text { As-Received } \\
\text { (Wt\% of } \\
\text { Total Solids) }\end{array}$ & $\begin{array}{c}\text { SRNL- } \\
\text { Washed (Wt\% } \\
\text { of Total } \\
\text { Solids) }\end{array}$ & $\begin{array}{c}\text { Ratio of } \\
\text { SRNL- } \\
\text { Washed to } \\
\text { As-Received }\end{array}$ \\
\hline $\mathrm{Al}$ & 6.18 & 8.91 & 1.4 \\
\hline $\mathrm{Fe}$ & 6.91 & 16.3 & 2.4 \\
\hline $\mathrm{Hg}$ & 1.23 & 2.22 & 1.8 \\
\hline $\mathrm{Mn}$ & 1.62 & 3.66 & 2.3 \\
\hline $\mathrm{Na}$ & 32.0 & 15.2 & 0.5 \\
\hline $\mathrm{U}$ & 2.38 & 5.33 & 2.2 \\
\hline
\end{tabular}

If one assumes iron is inert in the washing process (insoluble, is not removed during washing), iron can be used to calculate the amount of partially soluble and primarily soluble elements removed during washing. The results of these calculations, along with the percent soluble for aluminum and sodium are presented in Table 6. Inputs and calculations are given in Appendix E. For aluminum, 39\% was removed during washing. The washing process removed approximately $75 \%$ of the soluble aluminum as shown by the drop from $48 \%$ to $11 \%$ soluble. There is no evidence that washing removed insoluble aluminum. In fact, the data indicate that a small amount of aluminum may have precipitated, as suggested by the drop of aluminum to sulfur ratio in the washing supernatants (see Table 2). Because sodium was added during washing (sodium nitrite, $\mathrm{Pu} / \mathrm{Be}$ stream, Tank 40 supernatant), a percent removal (relative to the as-received sample) cannot be calculated. However, the data show that a significant of the original and added sodium was removed by the washing process. Also, the results show that approximately one fourth of the insoluble sodium dissolved and was removed during washing. 
Table 6. Aluminum and Sodium Solubility, Percent Removed During Washing, and Mass Insoluble based on $100 \mathrm{~g}$ Fe

\begin{tabular}{|l|c|c|}
\hline & Aluminum & Sodium \\
\hline $\begin{array}{l}\text { \% Soluble in SB5 As-Received Qualification } \\
\text { Sample }\end{array}$ & 48 & 96 \\
\hline $\begin{array}{l}\text { \% Soluble in the SRNL-Washed SB5 } \\
\text { Qualification Sample }\end{array}$ & 11 & 84 \\
\hline$\%$ Removed by Washing & 39 & $\mathrm{NA}^{\dagger}$ \\
\hline Mass Insoluble in As-Received Sample (g) & 47 & 20 \\
\hline Mass Insoluble in Washed Sample (g) & 49 & 14 \\
\hline$\%$ Increase (Decrease) in Insoluble Mass & 4 & $(26)$ \\
\hline
\end{tabular}

$\dagger$ The amount of sodium removed cannot be calculated because sodium (sodium nitrite, sodium in the $\mathrm{Pu} / \mathrm{Be}$ material) was added during the washing process.

For DWPF CPC processing, quantification of anions, inorganic carbon, and total base is needed. Anion and total inorganic carbon results were obtained from analysis of slurry samples diluted with DI water by a factor of 30 (nominal). These results were reported previously. ${ }^{9}$ For total base, slurry was titrated with 1-M nitric acid to $\mathrm{pH} 4$. Total base (moles of acid added to reach $\mathrm{pH}=7$ ) was determined from the titration curve. Anions, inorganic carbon, mercury, and base equivalents are presented in Table 7.

Table 7. Anions, Total Inorganic Carbon, Mercury, and Base Equivalents in the SC-6 SRAT Receipt

\begin{tabular}{|l|c|}
\hline Analysis & Result \\
\hline Fluoride (mg/kg slurry) & $<200$ \\
\hline Formate (mg/kg slurry) & $<200$ \\
\hline Chloride (mg/kg slurry) & 225 \\
\hline Nitrite (mg/kg slurry) & 8,660 \\
\hline Nitrate (mg/kg slurry) & 6,220 \\
\hline Phosphate (mg/kg slurry) & $<200$ \\
\hline Sulfate (mg/kg slurry) & 586 \\
\hline Oxalate (mg/kg slurry) & $<200$ \\
\hline Mercury (wt\% of total solids) & 2.22 \\
\hline Total Inorganic Carbon (mg/kg slurry) & 1,280 \\
\hline Base Equivalents (mol/L slurry) & 0.739 \\
\hline
\end{tabular}

Following each wash, sludge level was periodically recorded. Recordings were normalized relative to the total sludge slurry level for comparison between washes. There was a distinct difference between the sludge and supernatant during settling for all washes with no obvious suspended solids. The recordings are given in Appendix A, and the normalized data is presented graphically in Figure 1. As can be seen from Figure 1, there was no definite trend in settling during washing. That is, settling did not necessarily improve or worsen as washing progressed. For example, sludge appeared to settle much faster with Wash D versus Wash C, but then settling slowed with Wash E and F. 


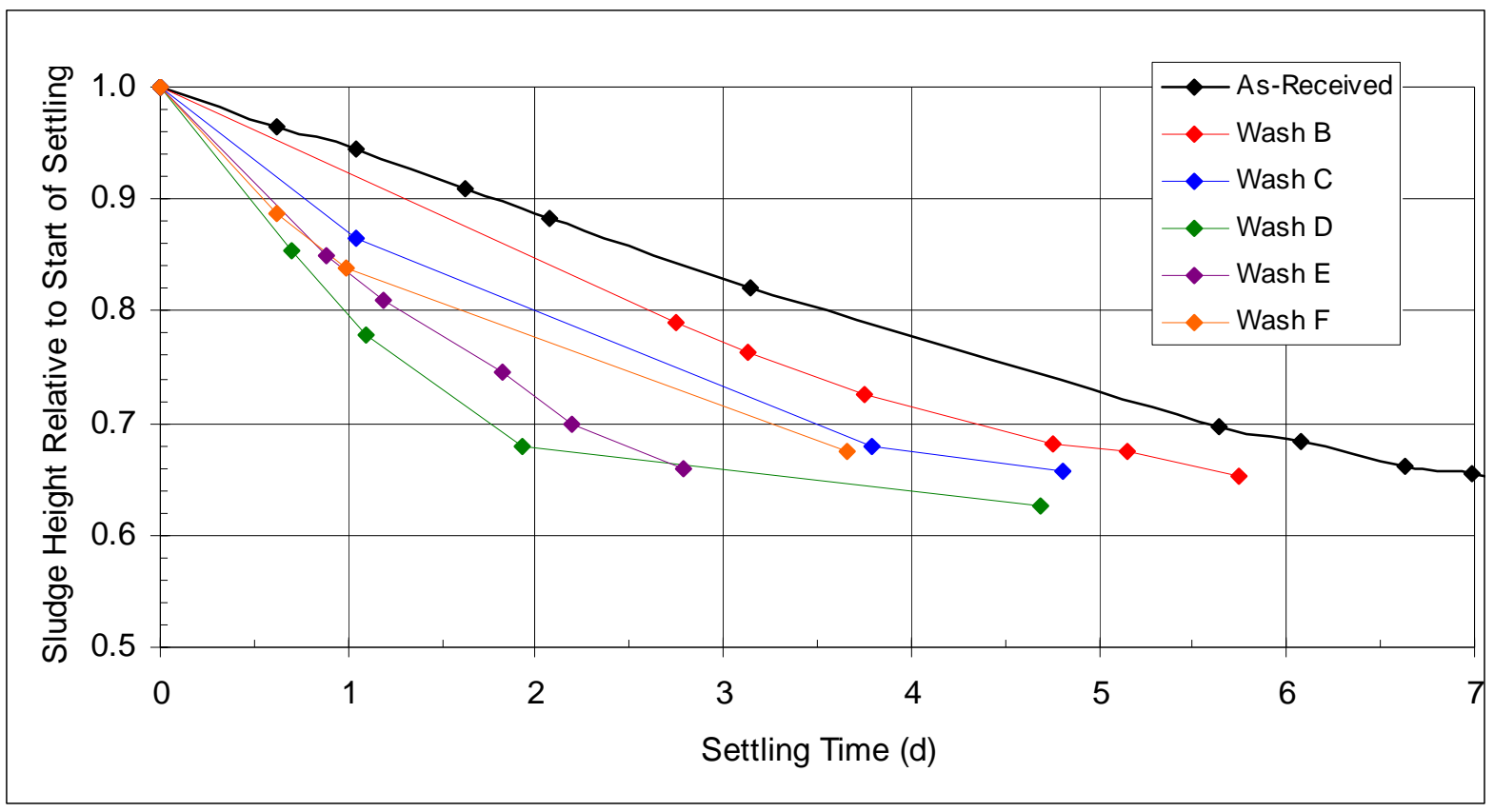

Figure 1. Sludge Settling During SRNL Washing of Tank 51 Qualification Sample 


\subsection{SEMIVOLATILE AND VOLATILE ANALYSIS OF THE SRNL WASHED SLUDGE BATCH 5 QUALIFICATION SAMPLE}

The SRNL-washed Tank 51 SB5 Qualification sample was analyzed for semivolatile organic compounds (SVOC) and volatile organic compounds (VOC). SVOC analytes have boiling points above $150^{\circ} \mathrm{C}$ while VOC analytes have boiling points below $150{ }^{\circ} \mathrm{C}$. Samples of the tank sludge were extracted with methylene chloride $\left(\mathrm{CH}_{2} \mathrm{Cl}_{2}\right)$ and the extractants analyzed by gas chromatography/mass spectrometry (GC/MS) for the presence of organic compounds.

\subsection{APPROACH}

\subsubsection{Semivolatile Organic Compound Analysis Experimental}

All solutions and extractions utilized glass vials with Teflon ${ }^{\circledR}$ caps to minimize the possibility of contamination from polymers and other organic compounds. For the semivolatile organic analyses, approximately $0.5 \mathrm{~g}$ tank sample was diluted with $19.5 \mathrm{~g}$ of deionized $\mathrm{H}_{2} \mathrm{O}$. Five grams of the diluted sludge was then extracted at both neutral (saturated $\mathrm{NaH}_{2} \mathrm{PO}_{4}$ ) and basic (saturated $\mathrm{NaNO}_{3}$ ) pH values with $10 \mathrm{~mL}$ of $\mathrm{CH}_{2} \mathrm{Cl}_{2}$ and either $5 \mathrm{~mL}$ of saturated $\mathrm{NaH}_{2} \mathrm{PO}_{4}$ or $\mathrm{NaNO}_{3}$. The methylene chloride layer from each extraction mixture was removed to a separate clean vial with a glass pipette and submitted to Analytical Development (AD) for analysis.

Samples were weighed and concentrated to $1 \mathrm{~mL}$ prior to analysis. Analytical separations were carried out on a Hewlett Packard 6890 gas chromatograph (GC), equipped with a $20 \mathrm{~m}$ DB-XLB column, with a $0.18 \mathrm{~mm}$ diameter and a $0.2 \mu \mathrm{m}$ film thickness. Quantification was performed using a Hewlett Packard 5973 mass selective detector. The mass spectrometer (MS) tuning was confirmed within 24 hours prior to each measurement using perfluorotributylamine.

\subsubsection{Volatile Organic Compound Analysis Experimental}

For the volatile organic analyses (VOA), approximately $0.10-0.14 \mathrm{~g}$ tank sample was diluted to approximately $14.5 \mathrm{~g}$ total mass. The diluted sludge slurry was submitted to AD for analysis.

The samples were analyzed by purge and trap GC/MS in order to identify organic compounds with boiling points below $150^{\circ} \mathrm{C}$. Calibration for VOC was made using five point 8260 standard, while calibration verification for benzene was performed at $0.05 \mathrm{mg} / \mathrm{L}$. Analytical separations were carried out on a Hewlett Packard 6890 gas chromatograph, equipped with a 18 m DB-624 column, with $0.18 \mathrm{~mm}$ diameter and $1.0 \mu \mathrm{m}$ film thickness. Quantification was performed using a Hewlett Packard 5973 mass selective detector. The MS tuning was confirmed within 24 hours prior to each measurement using perfluorotributylamine. The method detection limit was 0.01 $\mathrm{mg} / \mathrm{L}$ for VOCs.

\subsection{RESULTS AND DISCUSSION}

\subsubsection{Semivolatile Organic Compound Analysis Discussion}

The extractions were done at both basic and neutral $\mathrm{pH}$ in order to extract phenolic (aromatic compounds with hydroxyl substitution) compounds that may be deprotonated, and therefore more soluble in water than the extractant, $\mathrm{CH}_{2} \mathrm{Cl}_{2}$, at the elevated $\mathrm{pH}$ found in tank waste (12-13). 
Eight samples were submitted for semivolatile organic analysis (SVOA) including three replicates of the tank sample and a blank extracted at each of two $\mathrm{pH}$ values. The two $\mathrm{pH}$ values represented in-tank conditions and DWPF processing conditions. Phthalate, typically dibutylphthalate, at a concentration of $0.3 \mathrm{mg} / \mathrm{L}$, was found in three samples (two basic extractions and one neutral extraction) and the basic blank. Phthalates are common plasticizers easily extracted into $\mathrm{CH}_{2} \mathrm{Cl}_{2}$ and would indicate minor exposure of the extractant to plastics other than Teflon ${ }^{\circledR}$ despite efforts to minimize these exposures. The source of the phthalate is likely not the tank waste sludge. The method detection limit was $0.2 \mathrm{mg} / \mathrm{L}$.

\subsubsection{Volatile Organic Compound Analysis Discussion}

It was necessary to conduct the VOA and SVOA analyses separately since $\mathrm{CH}_{2} \mathrm{Cl}_{2}$ interferes with the VOC analysis. Due to the high activity of the sludge material, dilutions in the SRNL Shielded Cells were necessary prior to submission of the material to AD. One of the four replicates showed benzene at $0.10 \mathrm{mg} / \mathrm{L}$ (detection limit) and dimethylmercury at $0.04 \mathrm{mg} / \mathrm{L}$, but a duplicate analysis of this sample did not detect any analytes; indicating that these analytes may have been carry over from a previous sample. Additionally, dimethylmercury hydrolyzes in water and would not be expected in a sludge slurry sample, especially one diluted into water, as was the case in these samples. None of the remaining three samples showed any analytes when analyzed. 


\subsection{CHEMICAL PROCESS CELL SIMULATIONS}

The following subsections describe the DWPF CPC simulations using the SRNL-washed Tank 51 Sludge Batch 5 qualification sample adjusted to a higher insoluble solids. The simulations were performed in the SRNL Shielded Cells. The simulations (both a SRAT Cycle and SME Cycle) are referred to as SC-6 (the sixth Shielded Cells simulation since October 2006).

\subsection{APPROACH}

DWPF simulations (SRAT and SME cycles) using the SRNL washed Tank 51 SB5 qualification sample were conducted following procedures in the Process Science and Engineering Section procedure manual. ${ }^{10}$ A summary of each cycle is presented in Table 8.

Table 8. Summary of CPC Processing

\begin{tabular}{|c|c|}
\hline SRAT Cycle & SME Cycle \\
\hline $\begin{array}{l}\text { - } \text { Acid Calculation } \\
\text { - Heating of SRAT Receipt to } \\
93^{\circ} \mathrm{C} \\
\text { - Addition of nitric and formic } \\
\text { acids per acid calculation } \\
\text { - Heat to boiling } \\
\text { - Concentration (water removal) } \\
\text { - } \text { to a target wt } \% \text { total solids } \\
\text { Reflux to obtain a total time at } \\
\text { boiling of } 18 \text { hours }\end{array}$ & $\begin{array}{l}\text { - Addition and removal of water } \\
\text { to simulate addition and } \\
\text { removal of water from the } \\
\text { decontamination of } 5 \text { glass } \\
\text { canisters } \\
\text { - Addition of frit and dilute } \\
\text { formic acid in two batches to } \\
\text { target } 34 \% \text { waste loading } \\
\text { - Concentration (water removal) } \\
\text { to target } 45-50 \mathrm{wt} \% \text { total } \\
\text { solids. }\end{array}$ \\
\hline
\end{tabular}

The SB5 qualification CPC processing, designated as SC-6, was performed using a vessel designed to process one liter of sludge. For the in-cell run, the SRAT rig was assembled and tested in the SRNL Shielded Cells Mockup area and placed into the Shielded Cells fully assembled. A detailed description of the SRAT rig and testing of the rigs can be found in References 11 and 12. The intent of the equipment is to functionally replicate the DWPF processing vessels. The glass kettle is used to replicate both the SRAT and the SME, and it is connected to the SRAT Condenser and the Mercury Water Wash Tank (MWWT). Because the DWPF Formic Acid Vent Condenser (FAVC) does not directly impact SRAT and SME chemistry, it is not included in SRNL Shielded Cells CPC processing. Instead, a simple "cold finger" condenser is used to cool offgas to approximately $20^{\circ} \mathrm{C}$ below ambient to remove excess water before the gas reaches the gas chromatograph for characterization. The Slurry Mix Evaporator Condensate Tank (SMECT) is represented by a sampling bottle that is used to remove condensate through the MWWT. For the purposes of this paper, the condensers and wash tank are referred to as the offgas components. A sketch of the experimental setup is given as Figure 2. 


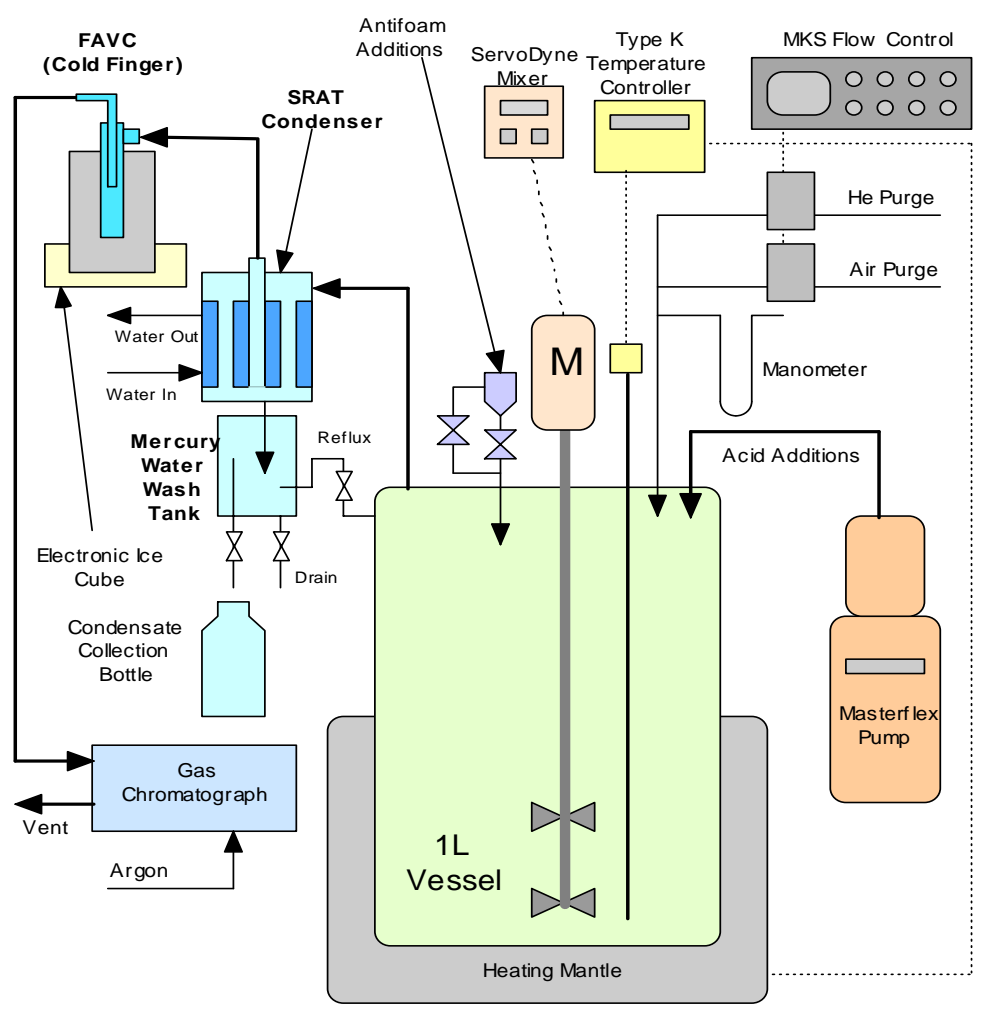

Figure 2. Schematic of SRAT Equipment Set-Up

Offgas hydrogen, oxygen, nitrogen, nitrous oxide, and carbon dioxide concentrations were measured during the experiments using in-line instrumentation (an Agilent M200 series micro GC). Helium was introduced at a concentration of $0.5 \%$ of the total air purge as an inert tracer gas so that total amounts of generated gas and peak generation rates could be calculated. During the runs, the kettle was visually monitored to observe reactions that were occurring to include foaming, air entrainment, rheology changes, loss of heat transfer capabilities, and offgas carryover. Observations were recorded in laboratory notebooks ${ }^{13-16}$ and are discussed in Sections 4.2 (SRAT cycle) and 4.3 (SME cycle).

Concentrated nitric acid (50-wt $\%)$ and formic acid $(90-\mathrm{wt} \%)$ were used to acidify the sludge and perform neutralization and reduction reactions during processing. The amounts of acid to add for each run were determined using the existing DWPF acid addition equation in the 6/1/07 version of the SRNL acid calculation spreadsheet ${ }^{17}$. The split of the acid was determined using the REDOX equation currently being used in DWPF processing ${ }^{18}$ and to be used in SB5 processing per the recommendation by Jantzen and Newell. ${ }^{19}$ To account for the reactions and anion destructions that occur during processing, assumptions about nitrite destruction, nitrite to nitrate conversion, and formate destruction were made. Acid stoichiometry, processing assumptions, and reflux time were based on CPC processing of SB5 simulant sludge slurry. ${ }^{2,20}$ 


\subsection{SRAT CYCLE RESULTS AND DISCUSSION}

\subsubsection{SRAT Receipt Acid Addition Calculations}

Following washing of the Tank 51 SB5 qualification sample, a portion of the sludge slurry was characterized to support requirements of the DWPF. Results of this characterization were previously discussed in Section 2.2. Note that the SC-6 SRAT Receipt material is the same material as the Wash F Add'l material.

The DWPF SRAT process relies upon use of the acid calculation to estimate the required acid necessary to complete reactions. This calculation uses measured analytical inputs. Errors in these measurements can result in too little acid being added resulting in incomplete reactions or too much acid being added resulting in excess formic acid causing high hydrogen generation rates. Analytical results necessary for the acid calculation are given in Table 9, along with other inputs necessary for the acid calculation. The inputs (e.g., acid stoichiometry, formic acid destruction, etc.) are based on simulant tests. ${ }^{2}$ 
Table 9. Acid Calculation Inputs for the Tank 51 Sludge Batch 5 Qualification (SC-6) CPC Simulation

\begin{tabular}{|c|c|c|}
\hline Measurement/Assumption & Units & Result \\
\hline Total Solids & $\mathrm{wt} \%$ of slurry & 17.1 \\
\hline Insoluble Solids & $\mathrm{wt} \%$ of slurry & 11.2 \\
\hline Soluble Solids & $\mathrm{wt} \%$ of slurry & 5.9 \\
\hline Calcined Solids & $\mathrm{wt} \%$ of slurry & 14.0 \\
\hline Slurry Density & $\mathrm{g} / \mathrm{mL}$ slurry & 1.14 \\
\hline Supernatant Density & $\mathrm{g} / \mathrm{mL}$ supernatant & 1.06 \\
\hline $\mathrm{Hg}$ & $\mathrm{wt} \%$ of total solids & 2.22 \\
\hline $\mathrm{Mn}$ & $\mathrm{wt} \%$ of calcined solids & 4.48 \\
\hline Nitrite & $\mathrm{mg} / \mathrm{kg}$ slurry & 8,660 \\
\hline Nitrate & $\mathrm{mg} / \mathrm{kg}$ slurry & 6,220 \\
\hline TIC & $\mathrm{mg} / \mathrm{kg}$ slurry & 1,280 \\
\hline Total Base & $\mathrm{mol} / \mathrm{L}$ slurry to $\mathrm{pH}=7$ & 0.739 \\
\hline $\begin{array}{l}\text { Conversion of Nitrite to Nitrate in } \\
\text { SRAT Cycle }\end{array}$ & $\mathrm{gmol} \mathrm{NO}_{3}^{-} / 100 \mathrm{gmol} \mathrm{NO}_{2}^{-}$ & 0 \\
\hline $\begin{array}{l}\text { Destruction of Nitrite in SRAT } \\
\text { and SME cycle }\end{array}$ & $\%$ of starting nitrite & 100 \\
\hline $\begin{array}{l}\text { Destruction of Formic acid } \\
\text { charged in SRAT }\end{array}$ & $\%$ of total formate & 25 \\
\hline $\begin{array}{l}\text { Percent Acid in Excess of } \\
\text { Stoichiometric Ratio }\end{array}$ & $\%$ & 130 \\
\hline $\begin{array}{l}\text { SRAT Product Target Total } \\
\text { Solids }\end{array}$ & $\mathrm{wt} \%$ of SRAT Product & 25 \\
\hline Predicted or Target REDOX & $\mathrm{Fe}^{+2} / \Sigma \mathrm{Fe}$ & 0.20 \\
\hline $\begin{array}{l}\text { No. of basis antifoam additions } \\
\text { added during SRAT cycle }\end{array}$ & $\mathrm{N} / \mathrm{A}$ & 12 \\
\hline $\begin{array}{l}\text { Destruction of Formic acid in } \\
\text { SME }\end{array}$ & $\begin{array}{c}\% \text { of SRAT Product } \\
\text { formate } \\
\end{array}$ & 10 \\
\hline Destruction of Nitrate in SME & $\begin{array}{l}\% \text { of SRAT Product } \\
\text { nitrate }\end{array}$ & 10 \\
\hline Assumed SME density & $\mathrm{g} / \mathrm{mL}$ slurry & 1.45 \\
\hline $\begin{array}{l}\text { No. of basis antifoam additions } \\
\text { added during SME cycle }\end{array}$ & N/A & 3 \\
\hline $\begin{array}{l}\text { Sludge Oxide Contribution in } \\
\text { SME (Waste Loading) }\end{array}$ & $\%$ sludge oxides & 34 \\
\hline SME Product Target Total Solids & $\mathrm{wt} \%$ of SME Product & 45 \\
\hline
\end{tabular}

The primary results of the acid calculation (the acid requirements) are presented in Table 10. It should be noted that there were no issues with the acid calculation inputs, specifically the total base measurement. SRNL preformed aluminum dissolution, washing and DWPF simulations with a Tank 51 sample (primarily Tank $11 \mathrm{HM}$ sludge) in late 2007 through early $2008 .^{21}$ The total base of that material was between 1.5 and $2.1 \mathrm{~mol} / \mathrm{L}$, depending on the sample preparation method (diluted or undiluted slurry). Also, results with undiluted slurry were difficult to repeat. There were no issues in titrating the SB5 sample; results were repeatable, and titration curves were smooth. The improved measurement of total base was likely due to the addition of Tank 7 and other chemical additions during washing which increased nitrite and nitrate (compared to the earlier Tank 51 aluminum dissolution sample), effectively lowering hydroxide (total base) in the SB5 sample. 
Table 10. SRAT Cycle Acid Requirements

\begin{tabular}{|l|c|}
\hline Parameter & Value \\
\hline $\begin{array}{c}\text { Calculated Stoichiometric Acid (100\% } \\
\text { stoichiometry), moles/L }\end{array}$ & 1.32 \\
\hline $\begin{array}{c}\text { Actual Acid to Add (130\% } \\
\text { stoichiometry), moles/L }\end{array}$ & 1.72 \\
\hline Ratio of Formic Acid to Total Acid & 0.85 \\
\hline
\end{tabular}

\subsubsection{SRAT Product Characterization Results and SRAT Cycle Observations}

Presented in Table 11, Table 12, Table 13, and Table 14 are the SC-6 SRAT Cycle product analytical results and peak gas generation results. Offgas data is shown graphically in Figure 3.

Table 11. Weight Percent Solids and Density of the SC-6 SRAT Product

\begin{tabular}{|l|c|}
\hline Analysis & Result \\
\hline Weight \% Total Solids (slurry basis) & 26.5 \\
\hline Weight \% Calcined Solids (slurry basis) & 18.8 \\
\hline Weight \% Insoluble Solids (slurry basis) & 14.9 \\
\hline Slurry Density (g/mL) & 1.22 \\
\hline Supernatant Density (g/mL) & 1.09 \\
\hline
\end{tabular}

Table 12. Anions, Total Inorganic Carbon, Mercury, and pH of the SC-6 SRAT Product

\begin{tabular}{|c|c|}
\hline Fluoride (mg/kg slurry) & $<800$ \\
\hline Formate (mg/kg slurry) & 57,400 \\
\hline Chloride (mg/kg slurry) & $<2,00$ \\
\hline Nitrite (mg/kg slurry) & $<800$ \\
\hline Nitrate (mg/kg slurry) & 39,100 \\
\hline Phosphate (mg/kg slurry) & $<800$ \\
\hline Sulfate (mg/kg slurry) & $<2,000$ \\
\hline Oxalate (mg/kg slurry) & $<800$ \\
\hline Mercury (wt\% of total solids) & 0.18 \\
\hline Total Inorganic Carbon (mg/kg slurry) & 431 \\
\hline $\mathrm{pH}$ & $8.27^{\dagger}$ \\
\hline
\end{tabular}

${ }^{\dagger} \mathrm{pH}$ was measured on a cooled SRAT product on the day following the conclusion of the SRAT cycle. This pH may be biased high due to carbon dioxide adsorption into the sample. 
Table 13. Concentrations of Elements in the SC-6 SRAT Product

\begin{tabular}{|c|c|}
\hline Element & $\begin{array}{c}\text { Wt\% of } \\
\text { Total Solids }\end{array}$ \\
\hline $\mathrm{Al}$ & 7.14 \\
\hline $\mathrm{Ca}$ & 1.13 \\
\hline $\mathrm{Ce}$ & 0.15 \\
\hline $\mathrm{Fe}$ & 13.0 \\
\hline $\mathrm{Mg}$ & 0.56 \\
\hline $\mathrm{Mn}$ & 3.08 \\
\hline $\mathrm{Na}$ & 12.8 \\
\hline $\mathrm{Ni}$ & 2.00 \\
\hline $\mathrm{P}$ & 0.12 \\
\hline $\mathrm{S}$ & $<0.29$ \\
\hline $\mathrm{Si}$ & 0.76 \\
\hline $\mathrm{U}$ & 4.88 \\
\hline $\mathrm{Zr}$ & 0.10 \\
\hline $\mathrm{Hg}$ & 0.18 \\
\hline
\end{tabular}

Table 14. Maximum Observed Hydrogen, Carbon Dioxide, and Nitrous Oxide Volume Percent and DWPF Scale Generation Rates during the SC-6 SRAT Cycle

\begin{tabular}{|c|c|c|}
\hline Gas & $\begin{array}{c}\text { Maximum } \\
\text { Observed } \\
\text { Volume\% }\end{array}$ & $\begin{array}{c}\text { Maximum Gas } \\
\text { Generation Rate } \\
\text { (DWPF Ib/h) }\end{array}$ \\
\hline Hydrogen & 0.599 & 0.495 \\
\hline Carbon Dioxide & 15.9 & 323 \\
\hline Nitrous Oxide & 3.31 & 66.8 \\
\hline
\end{tabular}




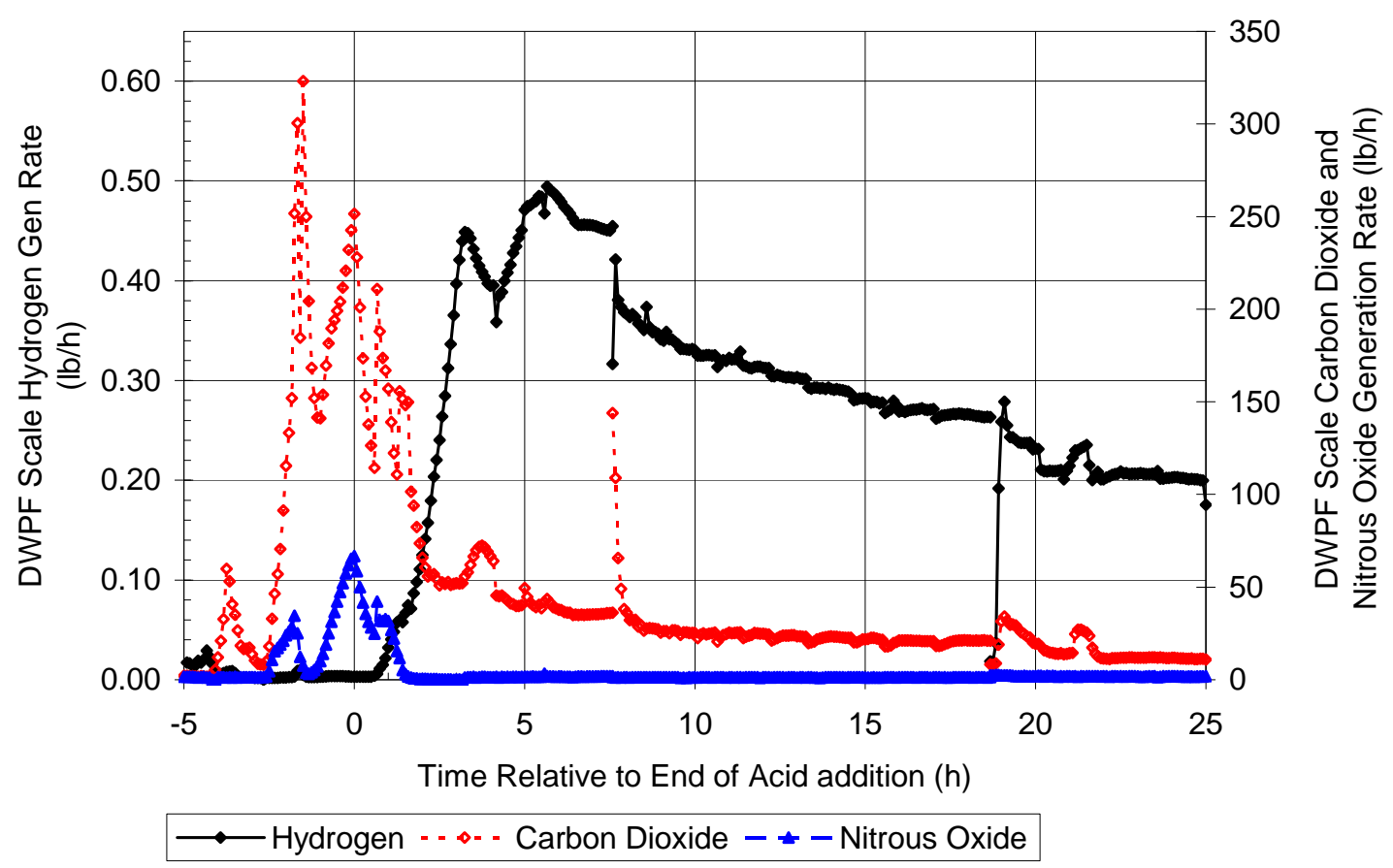

Figure 3. SC-6 DWPF Scale SRAT Cycle Gas Generation

The main observation from the SRAT processing was the material's tendency to foam. Antifoam was added to the SRAT twenty-one times. This included six planned additions (200 ppm initially, $100 \mathrm{ppm}$ between nitric and formic acid additions, $500 \mathrm{ppm}$ at the end of acid addition, and 100 ppm every 8 hours thereafter) and fifteen unplanned additions of $100 \mathrm{ppm}$ each. One $100 \mathrm{ppm}$ antifoam addition was made during formic acid addition. The remainder were made approximately hourly during boiling. SRNL is currently working with DWPF to investigate issues with the current antifoam supply and addition strategy. It is not clear if the need for antifoam was due to the sludge physical properties alone or from ineffective antifoam based on recent DWPF experience.

Other observations from SRAT testing were:

- Nitrite was destroyed to below $1,000 \mathrm{mg} / \mathrm{kg}$ (see Table 12).

- Mercury was removed to below the DWPF limit of $0.45 \mathrm{wt} \%$ of the total solids (see Table 12).

- The peak hydrogen generation rate was below the DWPF limit (see Table 14).

- There is no evidence to indicate that heat transfer capability was compromised. Controller output for the heating mantle was comparable to previous SRAT cycles, and there were no issues concentrating the SRAT product.

During the SRAT processing, the agitator was run at $550 \mathrm{rpm}$ throughout most of the cycle to provide adequate mixing after noting a very thick product after acid addition. Note that the SB4 Shielded Cells SRAT cycles were performed at about 250-300 rpm. This higher mixing speed was necessary because this SRAT material was thicker than comparable $(25 \mathrm{wt} \%$ total solids, 
nominally) SB4 SRAT material as quantified by the SRAT product yield stress measurements. The SB5 SRAT product had a yield stress of $9.9 \mathrm{~Pa}$ (see Section 6.2), while SRAT products from SB4 processing studies were 2.3 to $6.3 \mathrm{~Pa}^{22}$. Another difference in this testing is the fact that the SRAT processing did not improve the rheological properties, which is one of the goals of SRAT processing and has been seen in previous radioactive sludge testing.

The SRAT product supernatant was analyzed by Inductively Coupled Plasma - Atomic Emission Spectroscopy (ICP-AES) to determine if there were significant changes in solubility. Results were typical. During the SRAT cycle, soluble elemental concentrations of $\mathrm{Ba}, \mathrm{Ca}, \mathrm{Cd}, \mathrm{Fe}, \mathrm{K}$, $\mathrm{Mg}, \mathrm{Mn}, \mathrm{Na}, \mathrm{Si}$ and $\mathrm{Sr}$ increased, while the concentrations of $\mathrm{Al}, \mathrm{Cr}, \mathrm{P}$, and $\mathrm{S}$ decreased. The largest increase was seen in the Ca concentration, which increased by three orders of magnitude in the SRAT product supernatant. The largest decrease in solubility, two orders of magnitude, was seen for $\mathrm{Al}$, with a smaller quantifiable decrease of $22 \%$ for $\mathrm{S}$. The supernatant concentrations for the SRAT receipt and SRAT product and the calculated percent soluble are presented in Table 15. The percent soluble is calculated by converting the supernatant concentrations to a slurry basis using the wt $\%$ insoluble solids and dividing this by the elemental $\mathrm{wt} \%$ total solids converted to a slurry basis with the $\mathrm{wt} \%$ total solids:

Equation 1

$$
\% \text { Soluble }=\frac{C_{i} \cdot\left(1-W_{i s}\right)}{T_{i} \cdot W_{t s}} \times 10^{-4}
$$

where,

$C_{i}=$ concentration of element $\mathrm{i}$ in the supernatant, $\mathrm{mg} / \mathrm{kg}$

$W_{i s}=$ weight fraction insoluble solids in the slurry $\left(1-W_{\text {is }}=\right.$ weight fraction supernatant in a given slurry)

$T_{i}=$ weight fraction of element $i$ in the total solids

$W_{t s}=$ weight fraction total solids in the slurry. 
Table 15. Elements in SC-6 SRAT Receipt and SRAT Product Supernatants and Percent Soluble

\begin{tabular}{|c|c|c|c|c|}
\hline Element & $\begin{array}{c}\text { SRAT Receipt } \\
\text { Supernatant } \\
\text { Concentration } \\
\text { (mg/kg) }\end{array}$ & $\begin{array}{c}\text { SRAT } \\
\text { Product } \\
\text { Supernatant } \\
\text { Concentration } \\
\text { (mg/kg) }\end{array}$ & $\begin{array}{c}\text { Soluble } \\
\text { in SRAT } \\
\text { Receipt }\end{array}$ & $\begin{array}{c}\text { Soluble in } \\
\text { SRAT } \\
\text { Product }\end{array}$ \\
\hline $\mathrm{Al}$ & 1860 & $<4$ & $11 \%$ & $<0.02 \%^{\dagger}$ \\
\hline $\mathrm{Ba}$ & $<0.5$ & 1.1 & $<0.2 \%^{\dagger}$ & $0.4 \%$ \\
\hline $\mathrm{Ca}$ & 2.0 & 1,260 & $0.08 \%$ & $36 \%$ \\
\hline $\mathrm{Cd}$ & $<0.6$ & 0.92 & $<0.7 \%^{\dagger}$ & $0.7 \%$ \\
\hline $\mathrm{Cr}$ & 18 & $<0.6$ & $20 \%$ & $<0.5 \%{ }^{\dagger}$ \\
\hline $\mathrm{Fe}$ & $<20$ & 3.5 & $<0.06 \%^{\dagger}$ & $0.01 \%$ \\
\hline $\mathrm{K}$ & 96 & 167 & $>40 \%{ }^{\dagger}$ & $>50 \%$ \\
\hline $\mathrm{Mg}$ & $<3$ & 190 & $<0.3 \%{ }^{\dagger}$ & $11 \%$ \\
\hline $\mathrm{Mn}$ & $<0.7$ & 222 & $<0.01 \%^{\dagger}$ & $2 \%$ \\
\hline $\mathrm{Na}$ & 24,700 & 40,500 & $84 \%$ & $102 \%$ \\
\hline $\mathrm{P}$ & 10 & $<7$ & $3 \%$ & $<2 \%{ }^{\dagger}$ \\
\hline $\mathrm{S}$ & 237 & 185 & $>40 \%{ }^{\dagger}$ & $>20 \%{ }^{\dagger}$ \\
\hline $\mathrm{Si}$ & $<11$ & 44 & $<0.6 \%^{\dagger}$ & $2 \%$ \\
\hline
\end{tabular}

The hydrogen generation rate did not exceed the DWPF SRAT limit of $0.65 \mathrm{lb} / \mathrm{h}$ during the cycle. However, the hydrogen generation rate at the conclusion of eighteen hours of boiling (approximately twenty hours after the completion of acid addition) exceeded the DWPF SME cycle hydrogen generation rate of $0.223 \mathrm{lb} / \mathrm{h}$. Therefore, the SRAT vessel was reheated and boiled (under reflux conditions) to allow hydrogen generation to continue to drop. The high hydrogen generation (relative to the SME cycle limit) contributed to the decision, along with rheology, to add water to the SRAT product to lower the weight percent total solids from 26.5 wt $\%$ to $20 \mathrm{wt} \%$.

It should be noted that the offgas profile of the SRAT cycle was "normal". The bulk of the carbon dioxide was generated during and immediately after acid addition; nitrous oxide peaked at the conclusion of acid addition as nitrite was destroyed; and hydrogen generation peaked and then began to decline several hours after the nitrous oxide peak.

\subsection{SME CYCLE RESULTS AND DISCUSSION}

The SME cycle for run SC-6 was conducted following characterization of the SRAT product to ensure destruction of nitrite and adequate mercury removal. ${ }^{23}$ Based on a mass balance on the SRAT cycle, $521 \mathrm{~g}$ of SRAT product were utilized for the SME cycle test. A $169 \mathrm{~g}$ addition of deionized water (DI water) was made prior to starting the SME cycle to adjust the initial solids content from $26.5 \mathrm{wt} \%$ total solids to $20 \mathrm{wt} \%$ total solids to ensure adequate mixing during the test. Note that the yield stress of the SRAT product at $26.5 \mathrm{wt} \%$ total solids was too high for DWPF processing (see rheology results in Table 28 below). The SME cycle targeted a waste 
loading of $34 \mathrm{wt} \%$ using Frit 418, as recommended by Fox, Edwards and Peeler, ${ }^{24}$ and a final total solids target of $45 \mathrm{wt} \%$ as recommended by Lambert ${ }^{2}$. Five $109.7 \mathrm{~g}$ additions of DI water were made to the vessel and boiled off to replicate canister decontamination additions during SME processing. The frit addition was completed using two $91.39 \mathrm{~g}$ additions of Frit $418-$ Ferro Lot \#8 followed by $91.39 \mathrm{~g}$ of water and formic acid $(98.5 \mathrm{wt} \%$ water, $1.5 \mathrm{wt} \%$ formic acid). Following each frit/water/formic acid addition, $91.39 \mathrm{~g}$ of water was then removed by boiling. The final dewater to concentrate to the target solids was $155.1 \mathrm{~g}$. The average boil-up rate during the testing was $1.15 \mathrm{~g} / \mathrm{min}$, which scales to approximately $5,000 \mathrm{lb} / \mathrm{hr}$ based on a 6,000 gallon SRAT receipt volume.

A $200 \mathrm{ppm}$ antifoam addition was made at the start of the SME cycle and $100 \mathrm{ppm}$ antifoam additions were made prior to each dewater and frit addition. These $100 \mathrm{ppm}$ additions were made to ensure that foaming remained under control because deposits on the vessel walls prevented visual examination of the vessel contents and SRAT processing exhibited significant foaming.

No processing issues were noted during the SME cycle, although it should be noted that the antifoam addition strategy was different than typical runs since antifoam was added prior to each water or frit addition. The solids content of the final SME product was slightly above the targeted value (48.8 wt \% versus the $45 \mathrm{wt} \%$ target). Physical property measurements are shown in Table 16. The slurry from the SME cycle was also analyzed for anions and carbon. Total organic carbon is needed for the melter flammability controls. Data are shown in Table 17 and Table 18.

Table 16. Weight Percent Solids, pH, and Density of the SC-6 SME Product

\begin{tabular}{|c|c|}
\hline Analysis & Value \\
\hline $\mathrm{Wt} \%$ Total Solids (slurry basis) & 48.8 \\
\hline $\mathrm{Wt} \%$ Dissolved Solids (supernatant basis) & 14.0 \\
\hline $\mathrm{Wt} \%$ Insoluble Solids (slurry basis) & 40.4 \\
\hline $\mathrm{Wt} \%$ Soluble Solids (slurry basis) & 8.4 \\
\hline $\mathrm{Wt} \%$ Calcined Solids (slurry basis) & 42.9 \\
\hline SME Product $\mathrm{pH}$ & 8.77 \\
\hline Slurry Density (g/mL) & 1.44 \\
\hline Supernatant Density $(\mathrm{g} / \mathrm{mL})$ & 1.10 \\
\hline
\end{tabular}


Table 17. SC-6 SME Product Slurry Anion Concentrations

\begin{tabular}{|c|c|}
\hline Analyte & $\begin{array}{c}\text { Result (mg/kg } \\
\text { slurry) }\end{array}$ \\
\hline Fluoride & $<800$ \\
\hline Formate & 31,000 \\
\hline Chloride & $<800$ \\
\hline Nitrite & $<800$ \\
\hline Bromide & $<800$ \\
\hline Nitrate & 21,400 \\
\hline Phosphate & $<800$ \\
\hline Sulfate & $<800$ \\
\hline Oxalate & $<800$ \\
\hline
\end{tabular}

Table 18. SC-6 SME Product Carbon Analysis

\begin{tabular}{|c|c|}
\hline Analyte & $\begin{array}{c}\text { Ave (mg/kg } \\
\text { slurry) }\end{array}$ \\
\hline Total Carbon & 11,700 \\
\hline Total Inorganic Carbon & 1,720 \\
\hline Total Organic Carbon & 9,920 \\
\hline
\end{tabular}

Hydrogen generation during the SME cycle did not exceed the DWPF process limit of 0.223 $\mathrm{lb} / \mathrm{hr}$, as shown in Table 14. The offgas data is presented graphically in Figure 4. The maximum generation rate during the test was $0.15 \mathrm{lb} / \mathrm{hr}$ of hydrogen when scaled to DWPF processing conditions. The hydrogen generation rate slowly declined during the five dewater cycles that replicated canister decontamination dewatering. Hydrogen generation rates increased following the two frit additions. This increase is likely a result of the additional formic acid from the frit slurry. An increase in hydrogen generation rate was also noted at the end of the SME cycle as the slurry became more concentrated.

Table 19. Maximum Observed Hydrogen, Carbon Dioxide, and Nitrous Oxide Volume Percent and DWPF Scale Generation Rates during the SC-6 SME Cycle

\begin{tabular}{|c|c|c|}
\hline Gas & $\begin{array}{c}\text { Maximum } \\
\text { Observed } \\
\text { Volume\% }\end{array}$ & $\begin{array}{c}\text { Maximum Gas } \\
\text { Generation Rate } \\
\text { (DWPF lb/h) }\end{array}$ \\
\hline Hydrogen & 0.598 & 0.148 \\
\hline Carbon Dioxide & 7.72 & 45.0 \\
\hline Nitrous Oxide & 0.758 & 4.53 \\
\hline
\end{tabular}




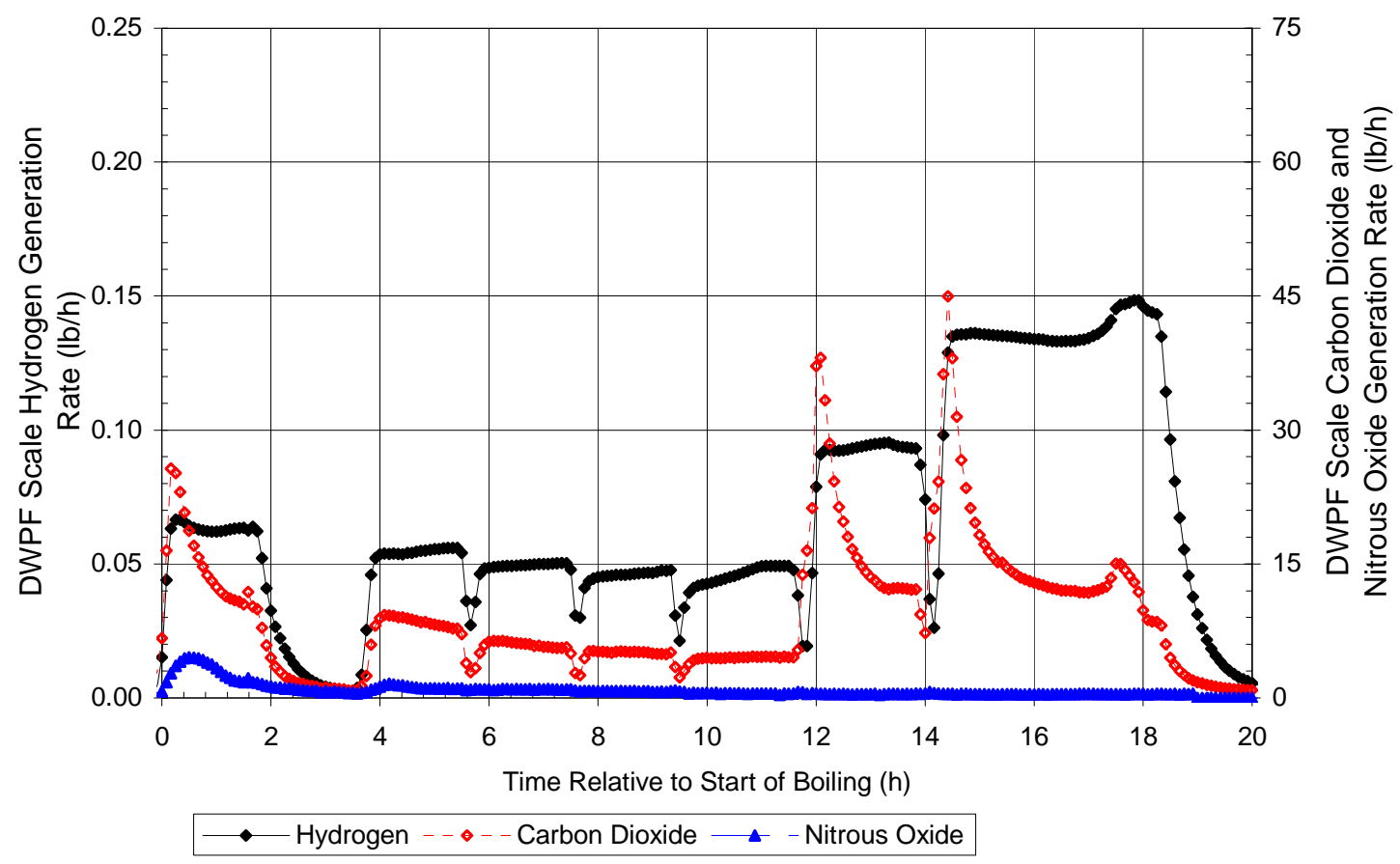

Figure 4. SC-6 DWPF Scale SME Cycle Gas Generation

\subsection{SC-6 CPC PROCESSING ANION DESTRUCTION AND CONVERSION}

Several inputs to the acid calculation involve assumptions for anion destruction and nitrite conversion to nitrate. Presented in Table 20 are the assumptions used in the SC-6 acid calculations and the corresponding results from the SC-6 processing and the applicable simulant run (see Appendix D for the SC-6 mass balance and anion destruction/conversion calculations). As can be seen, except for nitrite destruction and SRAT cycle formate destruction, the SC-6 results were not comparable with the assumptions or the simulant results. Based on the high hydrogen and detectable nitrous oxide during the SC-6 SRAT cycle, one would expect much less than $100 \%$ nitrite to nitrate destruction, and higher formate destruction. It should be noted that there is potential for substantial error in the SC-6 calculations. Primary sources of error include anion analyses of the SRAT receipt and SRAT and SME products ( $\pm 20 \%$ per SRNL-AD) and the SRAT and SME overall mass balance. Even with consideration of these error sources, it can be concluded that the anion chemistry of the radioactive material is different from the simulant. For example, in the radioactive demonstration, nitrate was created (from oxidation of nitrite), but in the simulant demonstration, nitrate was destroyed. 
Table 20. SC-6 Assumed and Measured Anion Destruction and Conversion with Comparison to Applicable Simulant Run

\begin{tabular}{|l|c|c|c|}
\hline & $\begin{array}{c}\text { Assumption } \\
\text { (Acid } \\
\text { Calculation } \\
\text { Input) }\end{array}$ & $\begin{array}{c}\text { SC-6 CPC } \\
\text { Processing }\end{array}$ & Simulant Run $^{\dagger}$ \\
\hline SRAT Cycle Nitrite Destruction (\%) & 100 & $>92$ & $>99.5$ \\
\hline SRAT Cycle Formate Destruction (\%) & 25 & 18 & 25 \\
\hline $\begin{array}{l}\text { SRAT Cycle Nitrite to Nitrate } \\
\text { Conversion (\%) }\end{array}$ & 15 & $100 *$ & -17 \\
\hline SME Cycle Formate Destruction (\%) & 0 & 32 & 7 \\
\hline SME Cycle Nitrate Destruction (\%) & 0 & 26 & 6 \\
\hline
\end{tabular}

${ }^{\top}$ CPC processing using Simulant SB5-D, Sludge Batch 5 simulant, with $130 \%$ acid stoichiometry. See Reference 2.

* This conversion is not reasonable based on the fact that nitrous oxide was measured in significant quantities in the offgas. That is, some nitrite was converted to NOx gas. This result is likely due to a combination of analytical errors in the SRAT receipt and product anion analyses and the overall SRAT cycle mass balance. 


\subsection{GLASS FABRICATION AND PCT}

\subsection{APPROACH}

\subsubsection{Glass Fabrication}

To fabricate the glass, 93.2 grams of the SME material were poured into a $95 \%$ platinum $/ 5 \%$ gold crucible. The SME material was first dried overnight at $110^{\circ} \mathrm{C}$. It was then heated at $10^{\circ} \mathrm{C}$ per minute to $1150{ }^{\circ} \mathrm{C}$ and held at $1150{ }^{\circ} \mathrm{C}$ for four hours. It was then quickly cooled to ambient temperature by placing the crucible in a shallow pan of water. No water contacted the glass during cooling. The resulting glass appeared black and shiny with no visible salt layer, crystals, or other inhomogeneities. This glass is referred to as the SB5 Qualification Glass.

\subsubsection{Glass Dissolution Methods and Analyses}

To support compositional analysis, a portion of the SB5 Qualification Glass had to be dissolved. In order to enhance dissolution, approximately $4 \mathrm{~g}$ of the glass was crushed and ground using agate cups, balls and caps in a mechanical pulverizing mixer mill. The glass was sieved and only the portion that passed through a 200 mesh $(<75 \mu \mathrm{m})$ brass sieve was used for the dissolutions. Weighed amounts (nominally $0.25 \mathrm{~g}$ ) of the crushed glass were then dissolved remotely by two different methods to ensure that all the elements of interest were dissolved and could be analyzed. The two methods were a sodium peroxide fusion at $675^{\circ} \mathrm{C}$ followed by a $\mathrm{HNO}_{3}$ uptake, and an acid dissolution in sealed vessels at $115^{\circ} \mathrm{C}$ using a combination of $\mathrm{HF}, \mathrm{HCl}$, and $\mathrm{HNO}_{3}$ acids. Boric acid was added to this latter dissolution method to complex excess fluoride. The solutions of the dissolved glass were diluted to known volumes so that approximately $15 \mathrm{~mL}$ aliquots could be safely removed from the Shielded Cells without exposing personnel to excess radiation. Four aliquots of the crushed SB5 Qualification Glass were dissolved by each technique. The aliquots were then submitted to AD, where they were analyzed by ICP-AES, radioactive counting techniques, and by Inductively Coupled Plasma - Mass Spectroscopy (ICP-MS). Concurrent with each set of dissolutions in the Shielded Cells, three samples of the Analytical Reference Glass (ARG) were also dissolved to determine if the dissolutions were complete and the resulting analyses accurate. With each set of samples sent to $\mathrm{AD}$, two samples of a multielement standard containing known concentrations of $\mathrm{Al}, \mathrm{B}, \mathrm{Fe}, \mathrm{Li}, \mathrm{Na}$, and $\mathrm{Si}$ were also submitted.

\subsubsection{Standard ASTM 1285 Leach Test Procedure}

The durability of the SB5 Qualification Glass was measured using the ASTM 1285 standard nuclear waste glass leach test using the procedure prescribed in Test Method A. ${ }^{25}$ This test is commonly referred to as the PCT. The purpose of the PCT is to confirm that the SB5 Qualification Glass has a durability that meets the criterion specified by the WAPS for repository acceptance $^{26}$. WAPS 1.3 specifies that the mean concentrations of $\mathrm{B}, \mathrm{Li}$, and $\mathrm{Na}$ in the leachate, after normalizing for the concentrations in the glass, shall each be less than those of the EA glass. ${ }^{27}$ These normalized concentrations represent the concentration of leached glass in PCT assuming all elements in the glass are soluble. DWPF complies with this criterion by demonstrating that the mean PCT results are at least two standard deviations below the mean PCT results of the EA glass. The ASTM 1285 Test Method A is a crushed glass $(-100$ to +200 mesh or 75 to $149 \mu \mathrm{m}$ ) leach test at $90{ }^{\circ} \mathrm{C}$ for 7 days using DI water in sealed stainless steel 
vessels. The test was performed in quadruplicate for the SB5 Qualification Glass. Duplicate blanks and triplicate samples of the standard glass [Accepted Reference Material (ARM)] and triplicate samples of the EA glass were also tested with the samples. In the PCT, $10 \mathrm{~mL}$ of DI water are used for each gram of glass. Nominally $1.7 \mathrm{~g}$ of glass and $17 \mathrm{~mL}$ of DI water were used in stainless steel vessels that were sealed tightly and weighed. After 7 days at $90{ }^{\circ} \mathrm{C}$, the containers were removed from the oven, allowed to cool, weighed to determine water loss, and then opened. Due to the radioactivity of the glass, the initial portion of the test was performed remotely in a Shielded Cell using manipulators. The leachates from each vessel were then decanted into a clean vessel. The radioactivities of the leachates were low enough so they could be transported to a radiochemical hood where they could be handled directly. The $\mathrm{pH}$ of each leachate was measured and then filtered through a $0.45 \mu \mathrm{m}$ filter and acidified to 1 volume percent $\mathrm{HNO}_{3}$. The leachates were then diluted and submitted to $\mathrm{AD}$, where the concentrations of $\mathrm{B}, \mathrm{Na}, \mathrm{Li}, \mathrm{Si}$, and $\mathrm{U}$ were determined using ICP-AES. Also, the concentrations of several radionuclides were measured in the glass and in the PCT leachates. These were measured by beta counting, gamma counting, and Inductively Coupled Plasma - Mass Spectroscopy (ICPMS).

\subsection{RESULTS AND DISCUSSION}

\subsubsection{Measured Composition of the SB5 Qualification Glass}

Table 21 shows the elemental (excluding oxygen) composition of the SB5 Qualification Glass. Essentially all of the $\mathrm{B}, \mathrm{Li}$ and $\mathrm{Si}$ and a portion of the $\mathrm{Na}$ are from the glass frit added to the SRAT product in order to prepare the glass. The frit used was Frit 418, which has a nominal composition of $76 \mathrm{wt} \% \mathrm{SiO}_{2}, 8 \mathrm{wt} \% \mathrm{~B}_{2} \mathrm{O}_{3}, 8 \mathrm{wt} \% \mathrm{Li}_{2} \mathrm{O}$ and $8 \mathrm{wt} \% \mathrm{Na}_{2} \mathrm{O}$. The analyzed composition of Frit 418 Ferro Lot \#8 (composition used during the qualification run) was 75.65 $\mathrm{wt} \% \mathrm{SiO}_{2}, 7.41 \mathrm{wt} \% \mathrm{~B}_{2} \mathrm{O}_{3}, 7.86 \mathrm{wt} \% \mathrm{Li}_{2} \mathrm{O}, 8.08 \mathrm{wt} \% \mathrm{Na}_{2} \mathrm{O}, 0.7 \% \mathrm{Al}_{2} \mathrm{O}_{3}$ (a frit impurity), and $0.27 \%$ other impurities. Depending upon the element, the results for the composition of the SB5 Qualification Glass represent an average of four to eight samples. For example, B is determined only by the peroxide fusion dissolution and $\mathrm{Na}$, only by the mixed acid. All the others are averages of eight results.

\footnotetext{
${ }^{*}$ Frit analysis results were reported in an email communication from B.A. Davis to M.E. Stone on July 1, 2008.
} 
Table 21. Average of Elemental Concentrations Measured in SB5 Qualification Glass by ICP-AES

\begin{tabular}{|c|c|c|}
\hline Element & Weight $^{{ }^{\mathrm{a}}}$ & \% RSD \\
\hline $\mathrm{Ag}$ & $<0.006$ & $\mathrm{~N} / \mathrm{A}$ \\
\hline $\mathrm{Al}$ & 3.84 & 1.99 \\
\hline $\mathrm{B}^{\mathrm{b}}$ & 1.39 & 1.81 \\
\hline $\mathrm{Ba}$ & 0.048 & 1.78 \\
\hline $\mathrm{Ca}^{\mathrm{c}}$ & 0.556 & 0.76 \\
\hline $\mathrm{Ce}^{\mathrm{c}}$ & 0.067 & 1.72 \\
\hline $\mathrm{Cr}$ & 0.023 & 3.43 \\
\hline $\mathrm{Cu}$ & 0.118 & 3.22 \\
\hline $\mathrm{Fe}$ & 6.40 & 2.08 \\
\hline $\mathrm{Gd}$ & 0.033 & 1.30 \\
\hline $\mathrm{K}$ & $<0.24$ & $\mathrm{~N} / \mathrm{A}$ \\
\hline $\mathrm{La}$ & 0.029 & 9.86 \\
\hline $\mathrm{Li}$ & 2.34 & 0.54 \\
\hline $\mathrm{Mg}$ & 0.267 & 3.73 \\
\hline $\mathrm{Mn}$ & 1.50 & 2.14 \\
\hline $\mathrm{Na}{ }^{\mathrm{c}}$ & 9.80 & 1.24 \\
\hline $\mathrm{Ni}{ }^{\mathrm{c}}$ & 0.927 & 2.00 \\
\hline $\mathrm{P}$ & 0.117 & 12.0 \\
\hline $\mathrm{Pb}$ & $<0.021$ & N/A \\
\hline $\mathrm{S}$ & $<0.13$ & N/A \\
\hline $\mathrm{Sb}$ & $<0.12$ & N/A \\
\hline $\mathrm{Si}{ }^{\mathrm{b}}$ & 25.8 & 2.29 \\
\hline $\mathrm{Sr}$ & 0.047 & 4.07 \\
\hline $\mathrm{Ti}$ & 0.026 & 3.08 \\
\hline $\mathrm{U}$ & 2.04 & 6.62 \\
\hline $\mathrm{Zr}^{\mathrm{c}}$ & 0.063 & 0.95 \\
\hline $\mathrm{c}$ & 0.114 & 0.80 \\
\hline
\end{tabular}

${ }^{\mathrm{a}}$ Results are averages of eight determinations unless otherwise noted.

${ }^{\mathrm{b}}$ Results of four samples dissolved by the peroxide fusion technique.

${ }^{\mathrm{c}}$ Results of four samples dissolved by the mixed acid technique.

The composition of the SB5 Qualification Glass in terms of oxides greater than $0.1 \mathrm{wt} \%$ is presented in Table 22. Note that this data was presented previously in Reference 28 . The targeted values in the third column are calculated from the analysis of the SB5 SRAT receipt (see Table 4 and the analyzed Frit 418 composition given above at a 34\% waste loading - calcined solids basis. The last column shows the relative difference of the measured from the targeted composition calculated from the following equation.

$$
100 \times(\text { Measured }- \text { Targeted }) / \text { Targeted }
$$


Table 22. Average Concentrations of Oxides with Concentrations $\geq 0.1$ Weight Percent in SB5 Qualification Glass Measured by ICP-AES

\begin{tabular}{|c|c|c|c|}
\hline Oxide & $\begin{array}{c}\text { Measured } \\
\text { Weight \% }\end{array}$ & $\begin{array}{c}\text { Targeted } \\
\text { Weight \% }\end{array}$ & $\begin{array}{c}\text { \% } \\
\text { Difference } \\
\text { from Target }\end{array}$ \\
\hline $\mathrm{Al}_{2} \mathrm{O}_{3}$ & 7.25 & 7.00 & 4 \\
\hline $\mathrm{B}_{2} \mathrm{O}_{3}{ }^{\mathrm{c}}$ & 4.44 & 5.28 & -16 \\
\hline $\mathrm{CaO}^{\mathrm{d}}$ & 0.78 & 0.77 & 1 \\
\hline $\mathrm{CuO}$ & 0.15 & 0.03 & 400 \\
\hline $\mathrm{Fe}_{2} \mathrm{O}_{3}$ & 9.15 & 9.69 & -6 \\
\hline $\mathrm{Li}_{2} \mathrm{O}^{\mathrm{d}}$ & 5.03 & 5.28 & -5 \\
\hline $\mathrm{MgO} \mathrm{MnO}$ & 0.44 & 0.44 & 0.4 \\
\hline $\mathrm{Na}_{2} \mathrm{O}^{\mathrm{d}}$ & 1.94 & 1.96 & -1 \\
\hline $\mathrm{NiO}^{\mathrm{d}}$ & 13.2 & 13.8 & -4 \\
\hline $\mathrm{P}_{2} \mathrm{O}_{5}$ & 0.27 & 1.24 & -5 \\
\hline $\mathrm{SO}_{4}$ & $<0.38$ & 0.20 & 34 \\
\hline $\mathrm{SiO}_{2}{ }^{\mathrm{c}}$ & 55.3 & 5.39 & N/A \\
\hline $\mathrm{U}_{3} \mathrm{O}_{8}$ & 2.41 & 2.61 & 8 \\
\hline $\mathrm{ZrO}_{2}$ & 0.15 & N/A & -8 \\
\hline
\end{tabular}

${ }^{a}$ Results are averages of eight determinations unless otherwise noted.

${ }^{\mathrm{b}}$ Calculated from SRAT receipt analysis (Table 4) and Frit 418 composition at a 34\% waste loading.

${ }^{c}$ Results of three samples dissolved by the peroxide fusion technique.

${ }^{\mathrm{d}}$ Results of four samples dissolved by the mixed acid technique.

\subsubsection{Processability of the SB5 Qualification Glass}

The measured SB5 Qualification Glass oxide concentrations reported in Table 23 were used to predict the properties of the glass based on the DWPF Product Composition Control System (PCCS) models. ${ }^{29}$ The predicted properties from this composition were then compared to SME acceptability criteria to evaluate if this glass did indeed meet the DWPF processing and product quality constraints. Based on the measured composition, all the predicted properties met the PCCS Measurement Acceptability Region (MAR) criteria. 
Table 23. Measured SB5 Qualification Glass Composition for Input into PCCS

\begin{tabular}{|c|c|c|c|}
\hline Oxide & Weight \% & Oxide & Weight \% \\
\hline $\mathrm{Al}_{2} \mathrm{O}_{3}$ & 7.25 & $\mathrm{Na}_{2} \mathrm{O}$ & 13.3 \\
\hline $\mathrm{B}_{2} \mathrm{O}_{3}$ & 4.44 & $\mathrm{Nd}_{2} \mathrm{O}_{3}$ & $0^{\dagger}$ \\
\hline $\mathrm{BaO}$ & 0.054 & $\mathrm{NiO}$ & 1.18 \\
\hline $\mathrm{CaO}$ & 0.78 & $\mathrm{P}_{2} \mathrm{O}_{5}$ & 0.27 \\
\hline $\mathrm{Ce}_{2} \mathrm{O}_{3}$ & 0.078 & $\mathrm{PbO}$ & $0^{\dagger}$ \\
\hline $\mathrm{Cr}_{2} \mathrm{O}_{3}$ & 0.034 & $\mathrm{SO}_{4}$ & $0^{\dagger}$ \\
\hline $\mathrm{CuO}_{2 n}$ & 0.15 & $\mathrm{SiO}_{2}$ & 55.2 \\
\hline $\mathrm{Fe}_{2} \mathrm{O}_{3}$ & 9.15 & $\mathrm{ThO}_{2}$ & $0^{\dagger}$ \\
\hline $\mathrm{K}_{2} \mathrm{O}$ & $0^{\dagger}$ & $\mathrm{TiO}_{2}$ & 0.044 \\
\hline $\mathrm{La}_{2} \mathrm{O}_{3}$ & 0.034 & $\mathrm{U}_{3} \mathrm{O}_{8}$ & 2.41 \\
\hline $\mathrm{Li}_{2} \mathrm{O}$ & 5.03 & $\mathrm{Y}_{2} \mathrm{O}_{3}$ & $0^{\dagger}$ \\
\hline $\mathrm{MgO}$ & 0.44 & $\mathrm{ZnO}$ & 0.069 \\
\hline $\mathrm{MnO}$ & 1.94 & $\mathrm{ZrO}_{2}$ & 0.15 \\
\hline $\mathrm{MoO} \mathrm{O}_{3}$ & $0^{\dagger}$ & $\mathbf{S U M}$ & $\mathbf{1 0 1 . 9 4}$ \\
\hline
\end{tabular}

$\dagger$ PCCS requires an input value for all the oxides listed in this table. Therefore, for oxides not detected or measured, a value of zero was entered into PCCS.

Some of the predicted properties of interest for the as measured SB5 Qualification Glass are provided in Table 24. In Table $24 \mathrm{NL}[\mathrm{B}(\mathrm{g} / \mathrm{L})], \mathrm{NL}[\mathrm{Li}(\mathrm{g} / \mathrm{L})]$, and $\mathrm{NL}[\mathrm{Na}(\mathrm{g} / \mathrm{L})]$ are the predicted normalized PCT releases based on these elements. These will be discussed further in a later section. The other PCCS results in Table 24 deal with the relative stability of the glass $\left(\Delta \mathrm{G}_{\mathrm{p}}\right.$ Value), the liquidus temperature $\left(\mathrm{T}_{\mathrm{L}}\right)$ prediction (in ${ }^{\circ} \mathrm{C}$ ), the viscosity prediction (in Poise) at $1150{ }^{\circ} \mathrm{C}$, and the sum of oxides (which PCCS requires to be between 95 and 105\%). PCCS also dictates the minimum concentration of $\mathrm{Al}_{2} \mathrm{O}_{3}$ in the glass to ensure glass homogeneity, which dictates that the concentration of $\mathrm{Al}_{2} \mathrm{O}_{3}$ in the glass be $\geq 4 \mathrm{wt} \%$ or $\geq 3 \mathrm{wt} \%$ with a sum of alkali $<19.3 \mathrm{wt} \%$. The next to the last row is a constraint associated with the possibility of nepheline formation in the glass. This value must be $>0.62$ to avoid nepheline formation. ${ }^{30}$ The last row of Table 24 indicates that all of the PCCS MAR criteria were met for the as-measured SB5 Qualification Glass.

All the results displayed in Table 24 meet the PCCS MAR criteria for processing this glass in the DWPF. In addition, the plots in Figure 5 reveal that the measured PCT releases for the SB5 Qualification Glass are predictable by the $\Delta \mathrm{G}_{\mathrm{p}}$ models of PCCS. 
Table 24. PCCS Results for SB5 Qualification Glass

\begin{tabular}{|c|c|}
\hline Glass Property & Calculated Value \\
\hline$\Delta \mathrm{G}_{\mathrm{p}}$ Value & -9.831 \\
\hline $\mathrm{NL}[\mathrm{B}(\mathrm{g} / \mathrm{L})]$ & 0.759 \\
\hline $\mathrm{NL}[\mathrm{Li}(\mathrm{g} / \mathrm{L})]$ & 0.789 \\
\hline $\mathrm{NL}[\mathrm{Na}(\mathrm{g} / \mathrm{L})]$ & 0.759 \\
\hline $\mathrm{T}_{\mathrm{L}}$ Prediction $\left({ }^{\circ} \mathrm{C}\right)$ & 878.4 \\
\hline Viscosity Prediction (Poise) $^{\circ}$ & 76.6 \\
\hline Sum of Oxides $(\%)^{\mathrm{a}}$ ) & $101.94^{\mathrm{a}}$ \\
\hline $\mathrm{Al}_{2} \mathrm{O}_{3} \mathrm{wt}^{\circ}$ & 7.249 \\
\hline Nepheline Constraint Value & 0.730 \\
\hline All PCCS MAR Criteria & Yes \\
Met & \\
\hline
\end{tabular}

${ }^{\mathrm{a}}$ Note that PCCS does not include $\mathrm{SO}_{4}$ in its sum of oxides
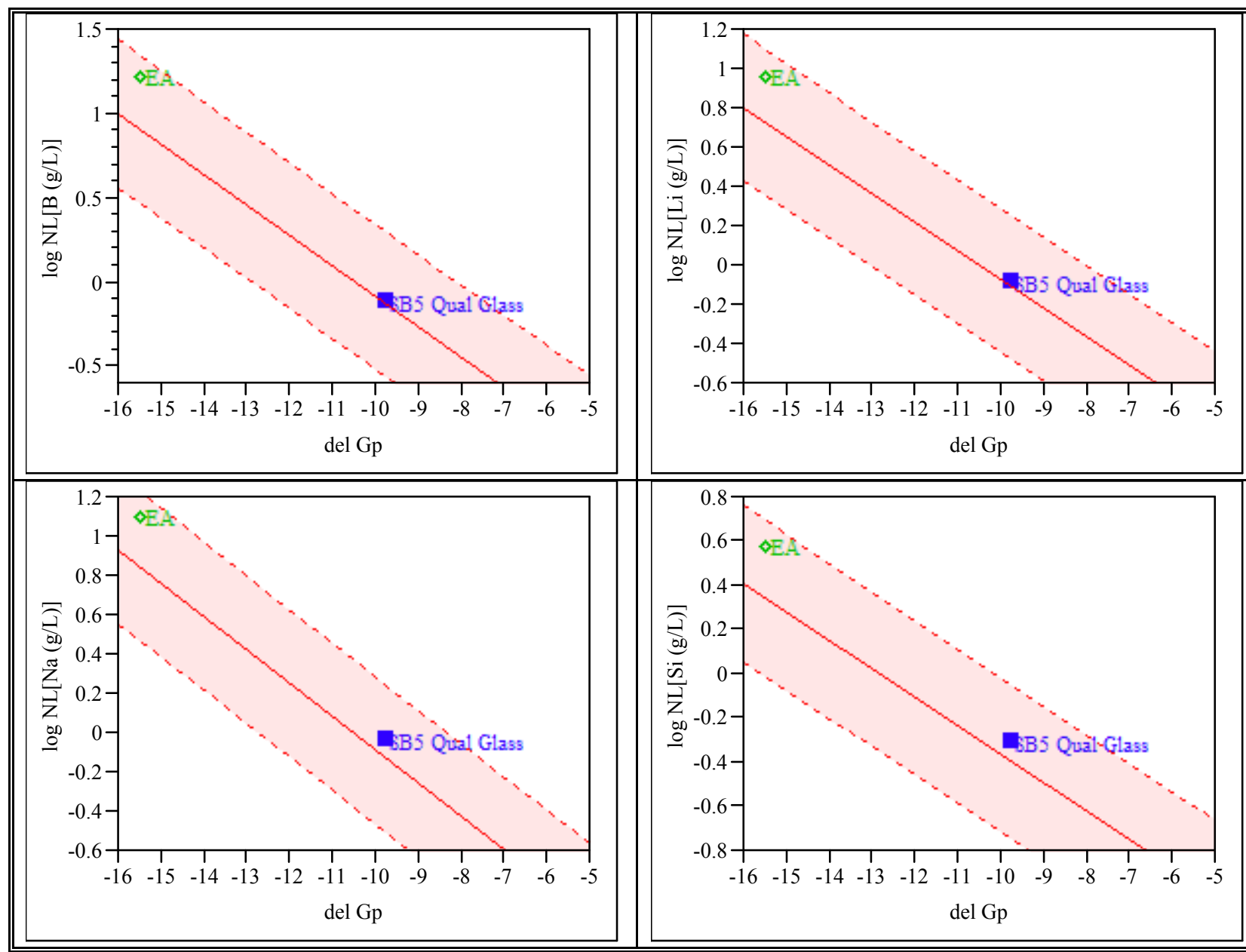

Figure 5. Predictability of the PCT Response of the SB5 Qualification Glass 


\subsubsection{Estimated Waste Loading for the SB5 Qualification Glass}

Another calculation of interest in this analysis is that of WL. DWPF calculates WL based on the measured concentration of $\mathrm{Li}$ in the product glass. For the SB5 Qualification Glass, the elemental $\mathrm{Li}$ content (from Table 21) is $2.34 \mathrm{wt} \%$ or $5.03 \mathrm{wt} \% \mathrm{Li}_{2} \mathrm{O}$, and the sum of oxides as computed by PCCS is $101.94 \mathrm{wt} \%$ (from Table 24). The measured $\mathrm{Li}_{2} \mathrm{O}$ content of the specific lot of frit (Ferro Lot \#8) used is $7.86 \mathrm{wt} \%$. Using these results to compute WL, PCCS yields a waste loading of $37.2 \%$ rather than the targeted $34 \%$. The calculations are shown below.

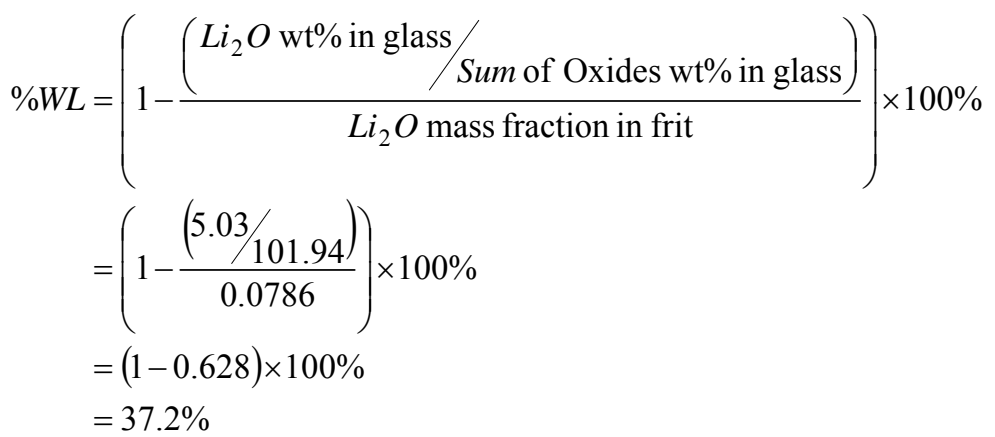

Due to analytical uncertainty around the Li measurement, another estimate of waste loading was made using a sludge oxide not present in Frit 418. $\mathrm{Al}_{2} \mathrm{O}_{3}$ was used to make this estimate. In the SRAT product, the $\mathrm{Al}_{2} \mathrm{O}_{3}$ content was $19.07 \mathrm{wt} \%$ in the calcined solids, and from Table 22, $\mathrm{Al}_{2} \mathrm{O}_{3}$ in glass was measured at $7.25 \mathrm{wt} \%$. As shown below, using the alumina concentration measured for the Qualification Glass to compute an estimate of WL yields 37.3\%, which is very close to the calculated WL for $\mathrm{Li}_{2} \mathrm{O}$. This calculation however, did not take into consideration any impurities of $\mathrm{Al}_{2} \mathrm{O}_{3}$ that would be in the frit. This suggests that waste loading can be estimated by using different components, but analytical uncertainty and how it directly influences the estimated WL continues to be an issue which needs to be further addressed.

$$
\begin{aligned}
\% W L & =\left(\frac{\left(\mathrm{Al}_{2} \mathrm{O}_{3} \mathrm{wt} \% \text { in glass } / \text { Sum of Oxides wt } \% \text { in glass }\right)}{\mathrm{Al}_{2} \mathrm{O}_{3} \text { mass fraction in SRAT product }}\right) \times 100 \% \\
& =\left(\frac{(7.25 / 101.94)}{0.1907}\right) \times 100 \% \\
& =37.3 \%
\end{aligned}
$$

\subsubsection{Results of the ASTM 1285 Leach Test (Product Consistency Test)}

Quadruplicate samples of the SB5 Qualification Glass were subjected to the PCT along with triplicate blanks, triplicate samples of the ARM standard glass and the EA glass as prescribed by the ASTM procedure, Test Method A. ${ }^{25}$ The results for the triplicate ARM standard glasses and the triplicate blanks indicated that the test was performed and controlled as prescribed in the ASTM Procedure. These results are summarized in Appendix B. The procedure also states that a certified multi-element standard prepared by a qualified vendor be analyzed with the leachates. The standard contains known concentrations of $\mathrm{B}, \mathrm{Na}, \mathrm{Li}$, and $\mathrm{Si}$, elements that are measured in the PCT. Results for the triplicate analyses of the multi-element standard are also summarized in 
Appendix B. These results show that the ICP-AES had been correctly calibrated and operated; consequently, the analytical results for the leachates were reliable and acceptable.

In the PCT, the normalized release values are based on the measure of the concentration of a specific element dissolved in the PCT leachate with respect to the concentration of that element in the original glass. The calculated normalized release rate is then a measure of the amount of glass dissolved in the leachate based upon that specific element if all the leached elements in the glass are soluble in the leachate. Results for the averaged normalized releases, based on $\mathrm{B}, \mathrm{Na}$, $\mathrm{Li}$, and $\mathrm{Si}$ are given in Table 25 , along with the range of \%RSD values for the replicate tests. Results for the EA glass are also presented along with the averages of the measured $\mathrm{pH}$ values.

For the SB5 Qualification Glass and the EA glass the RSD ranges are small for the calculated normalized releases indicating good precision in the replicate tests. Normalized releases for the EA glass based on $\mathrm{B}, \mathrm{Na}, \mathrm{Li}$, and $\mathrm{Si}$ are in reasonable agreement with consensus values measured by SRNL researchers in previous PCTs with the EA glass. ${ }^{27}$ As shown in Table 25, the results for the B and Li releases for the SB5 Qualification Glass are in reasonable agreement with values predicted by PCCS. The Na release is slightly higher than predicted but still within the confidence bands (as shown in Figure 5). The results in Table 25 clearly show that the SB5 Qualification Glass is more durable than the EA glass. In fact, the normalized results for the SB5 Qualification Glass based on B, Na, and Li are more than an order of magnitude less than those for the EA glass, demonstrating that the SB5 Qualification Glass meets the durability criterion set forth in the WAPS for a Federal geologic repository. ${ }^{26}$ The lower durability of the EA glass is also indicated by the higher $\mathrm{pH}$ of the final leachates for the EA glass. The $\mathrm{pH}$ increases are a result of the exchange of sodium, lithium, and other cations in the glass with hydrogen ions in the water.

Table 25. Average PCT Results for EA and the SB5 Qualification Glasses

\begin{tabular}{|c|c|c|c|c|c|c|}
\hline Glass ID $^{\mathbf{a}}$ & $\begin{array}{c}\text { NL (B) } \\
\mathbf{g} / \mathbf{L}\end{array}$ & $\begin{array}{c}\text { NL (Na) } \\
\mathbf{g} / \mathbf{L}\end{array}$ & $\begin{array}{c}\text { NL (Li) } \\
\mathbf{g} / \mathbf{L}\end{array}$ & $\begin{array}{c}\text { NL (Si) } \\
\mathbf{g} / \mathbf{L}\end{array}$ & $\mathbf{\%} \mathbf{~ R S D}$ & $\mathbf{p H}$ \\
\hline EA & 16.4 & 12.7 & 9.2 & 3.9 & $1.2-1.5^{\mathrm{b}}$ & 11.8 \\
\hline SB5-Qual & 0.75 & 0.92 & 0.82 & 0.49 & $1.8-2.2^{\mathrm{c}}$ & 11.0 \\
\hline $\begin{array}{c}\text { SB5-Qual } \\
\text { Predicted by } \\
\text { PCCS }\end{array}$ & 0.759 & 0.759 & 0.789 & NA & NA & NA \\
\hline
\end{tabular}

${ }^{a}$ PCT performed remotely in the Shielded Cells of SRNL.

${ }^{\mathrm{b}}$ Range of RSD values for results of test performed in triplicate.

${ }^{\mathrm{c}}$ Range of RSD values for results of test performed 4 times.

The concentrations of nine radionuclides were measured in the PCT leachates for the SB5 Qualification Glass and in the glass itself in order to compare the normalized releases based on these radionuclides to those based on $\mathrm{B}, \mathrm{Li}$, or $\mathrm{Na}$. This was done to test the hypothesis that the normalized releases of glass based on the radionuclides are not higher than the normalized releases based on $\mathrm{B}, \mathrm{Li}$, or $\mathrm{Na}$. Results for the normalized releases along with the analytical method used to measure the radionuclides in the glass and in the PCT leachates are presented in Table 26. The reported concentrations of radionuclides in Table 26 are the averages of four dissolutions of the SB5 Qualification Glass. The reported radionuclide concentrations found in 
the PCT leachates are from four replicates of the glass subjected to the PCT-Method A. The normalized releases for the glass based on each radionuclide in Table 26 were calculated by dividing the concentration of each radionuclide in the PCT leachate by its respective concentration in the glass.

Table 26. PCT Results for Measured Radionuclides in SB5 Qualification Glass

\begin{tabular}{|c|c|c|c|c|}
\hline Radionuclide, $\mathbf{i}$ & $\begin{array}{c}\text { Concentration in } \\
\text { Glass }\end{array}$ & $\begin{array}{c}\text { Concentration in } \\
\text { Leachate }\end{array}$ & NL(i) g/L & $\begin{array}{c}\text { Analytical } \\
\text { Method }\end{array}$ \\
\hline $\mathrm{Zr}-93$ & $1.64 \mathrm{E}+02 \mu \mathrm{g} / \mathrm{g}$ & $2.98 \mathrm{E}+01 \mu \mathrm{g} / \mathrm{L}$ & 0.19 & ICP-MS \\
\hline $\mathrm{Sr}-90$ & $1.67 \mathrm{E}+10 \mathrm{dpm} / \mathrm{g}$ & $1.16 \mathrm{E}+09 \mathrm{dpm} / \mathrm{L}$ & 0.069 & $\beta$ Counting \\
\hline $\mathrm{Cs}-137$ & $2.89 \mathrm{E}+08 \mathrm{dpm} / \mathrm{g}$ & $1.00 \mathrm{E}+08 \mathrm{dpm} / \mathrm{L}$ & 0.35 & $\gamma$ Counting \\
\hline $\mathrm{Sm}-151$ & $8.46 \mathrm{E}+00 \mu \mathrm{g} / \mathrm{g}$ & $7.79 \mathrm{E}-01 \mu \mathrm{g} / \mathrm{L}$ & 0.092 & ICP-MS \\
\hline $\mathrm{Eu}-154$ & $2.31 \mathrm{E}+07 \mathrm{dpm} / \mathrm{g}$ & $3.39 \mathrm{E}+06 \mathrm{dpm} / \mathrm{L}$ & 0.15 & $\gamma$ Counting \\
\hline $\mathrm{U}-235$ & $1.35 \mathrm{E}+02 \mu \mathrm{g} / \mathrm{g}$ & $4.38 \mathrm{E}+01 \mu \mathrm{g} / \mathrm{L}$ & 0.32 & ICP-MS \\
\hline $\mathrm{U}-238$ & $1.92 \mathrm{E}-02 \mathrm{~g} / \mathrm{g} \mathrm{glass}$ & $5.93 \mathrm{E}-03 \mathrm{~g} / \mathrm{L}$ & 0.31 & ICP-MS \\
\hline Total U & $2.04 \mathrm{E}-02 \mathrm{~g} / \mathrm{g} \mathrm{glass}$ & $5.96 \mathrm{E}-03 \mathrm{~g} / \mathrm{L}$ & 0.29 & ICP-AES \\
\hline $\mathrm{Pu}-239$ & $1.34 \mathrm{E}+02 \mu \mathrm{g} / \mathrm{g}$ & $2.22 \mathrm{E}+01 \mu \mathrm{g} / \mathrm{L}$ & 0.17 & ICP-MS \\
\hline $\mathrm{Pu}-240$ & $1.33 \mathrm{E}+01 \mu \mathrm{g} / \mathrm{g}$ & $1.94 \mathrm{E}+00 \mu \mathrm{g} / \mathrm{L}$ & 0.15 & ICP-MS \\
\hline
\end{tabular}

In Table 26 note that the radionuclides do indeed indicate normalized releases that are less than the average normalized releases based on B, Li, or Na for the SB5 Qualification Glass (see Table 25). This trend was also observed for a glass taken from the DWPF pour stream during processing of $\mathrm{SB}^{31}$ and for a glass prepared at SRNL as part of the qualification of SB4. ${ }^{32}$ 


\subsection{RHEOLOGY}

\subsection{APPROACH}

Rheological properties of radioactive samples are determined using a Haake M5/RV30 rotoviscometer. The M5/RV30 is a Searle sensor system, where the bob rotates and the cup is fixed. The torque and rotational speed of the bob are measured. Heating/cooling of the cup/sample/bob is through the holder that holds the cup. The shear stress is determined from the torque measurement and is independent of the rheological properties. Conditions that impact the measured torque are; slip (material does not properly adhere to the rotor or cup), phase separation (buildup of liquid layer on rotor), sedimentation (particles settling out of the shearing zone), homogeneous sample (void of air), lack of sample (gap not filled), excess sample (primarily impacts rheologically thin fluids), completely filling up the void below the bob (air buffer that is now filled with fluid) and Taylor vortices. The first five items yield lower stresses and the last three add additional stresses. The shear rate is geometrically determined using the equations of change (continuity and motion) and is that for a Newtonian fluid. This assumption also assumes that the flow field is fully developed and the flow is laminar. The shear rate can be calculated for non-Newtonian fluid using the measured data and fitting this data to the rheological model or corrected as recommended by Darby ${ }^{33}$. In either case, for shear thinning non-Newtonian fluids typical of Savannah River Site (SRS) sludge wastes, the corrected shear rates are greater than their corresponding Newtonian shear rates, resulting in a thinner fluid. Correcting the flow curves will not be performed in this task, resulting in a slightly more viscous fluid.

The bob typically used for measuring tank sludge or SRAT product is the MV I rotor. For SME product, the MV II rotor is used to perform the measurements, due to the larger frit particles that are present in the SME product. The MV II has a larger gap to accommodate the larger frit particles. The shape, dimensions, and geometric constants for the MV I and MV II rotors are provided in Table 27.

Prior to performing the measurements, the rotors and cups are inspected for physical damage. The torque/speed sensors and temperature bath are verified for functional operability using a bob/cup combination with a National Institute of Standards and Technology (NIST) traceable Newtonian oil standard, using the MV I rotor. The resulting flow curves are then fitted as a Newtonian fluid and this calculated viscosity must be within $\pm 10 \%$ of the reported NIST viscosity at a given temperature for the system to be considered functionally operable. A N10 oil standard was used to verify system operability prior to the sludge measurements.

The flow curves for the sludge are fitted to the down curves using the Bingham Plastic rheological model, Equation 2, where $\tau$ is the measured stress $(\mathrm{Pa}), \tau_{\mathrm{o}}$ is the Bingham Plastic yield stress $(\mathrm{Pa}), \mu_{\infty}$ is the plastic viscosity $(\mathrm{Pa} \cdot \mathrm{sec})$, and $\dot{\gamma}$ is the measured shear rate $\left(\mathrm{sec}^{-1}\right)$. During all these measurements, the sample remained in the cup for the $2^{\text {nd }}$ measurement, due to the sample availability.

Equation 2

$$
\tau=\tau_{o}+\mu_{\infty} \dot{\gamma}
$$


Table 27. MV I and MV II Rotor Specifications and Flow Curve Program

\begin{tabular}{|c|c|c|c|}
\hline Rotor Design & \multicolumn{3}{|c|}{ Dimensions and Flow Curve Program } \\
\hline & Rotor Type & MV I & MV II \\
\hline & Rotor radius $-\mathrm{R}_{\mathrm{i}}(\mathrm{mm})$ & 20.04 & 18.40 \\
\hline & Cup Radius - $\mathrm{R}_{\mathrm{a}}(\mathrm{mm})$ & 21.0 & 21.0 \\
\hline & Height of rotor -L (mm) & 60 & 60 \\
\hline & $\begin{array}{l}\text { Sample Volume }\left(\mathrm{cm}^{3}\right) \\
\text { minimum }\end{array}$ & 40 & 55 \\
\hline & A factor $(\mathrm{Pa} / \%$ torque $)$ & 3.22 & 3.76 \\
\hline & $\mathrm{M}$ factor $\left(\mathrm{s}^{-1} / \% \mathrm{RPM}\right)$ & 11.7 & 4.51 \\
\hline & Shear rate range $\left(\mathrm{s}^{-1}\right)$ & $0-600$ & $0-300$ \\
\hline & Ramp up time (min) & 5 & 5 \\
\hline & Hold time (min) & 1 & 1 \\
\hline & Ramp down time (min) & 5 & 5 \\
\hline
\end{tabular}

\subsection{RESULTS AND DISCUSSION}

Given in Table 28 are the results of rheology measurements (yield stress and consistency) for slurry samples at various stages of SB5 processing. These results show that:

- Tank 51 slurry as processed as described above is rheologically acceptable for DWPF processing at $11.2 \mathrm{wt} \%$ insoluble solids.

- SRAT product at $26.5 \mathrm{wt} \%$ total solids (14.9 $\mathrm{wt} \%$ insoluble solids) has a yield stress that exceeds the DWPF SRAT limit $(10 \mathrm{~Pa})$, while yield stress at $20 \mathrm{wt} \%$ total solids is acceptable. The yield stress of the SC-6 slurry was not reduced during SRAT processing, which is one of the goals of SRAT processing and has been typically seen in previous radioactive sludge demonstrations.

- Yield stress of the SC-6 SME product exceeds the DWPF limit of $15 \mathrm{~Pa}$, but has a yield stress consistent with previous SME products qualified for DWPF processing. The wt $\%$ total solids of this material were 48.8. The material would likely be rheologically acceptable compared to the DWPF limit at the target $45 \mathrm{wt} \%$ total solids.

Flow curves (shear stress vs. shear rate) for these samples are given in Appendix C. 
Table 28. Rheology Measurements of Sludges, SRAT Products, and SME Products.

\begin{tabular}{|c|c|c|c|c|c|}
\hline Sample & $\begin{array}{c}\text { Weight } \\
\text { Percent } \\
\text { Insoluble } \\
\text { Solids }\end{array}$ & $\begin{array}{l}\text { Yield } \\
\text { Stress } \\
\text { (Pa) }\end{array}$ & $\begin{array}{c}\text { Consistency } \\
\text { (cP) }\end{array}$ & $\begin{array}{c}\text { DWPF Design } \\
\text { Basis Yield } \\
\text { Stress (Pa) } \\
\end{array}$ & $\begin{array}{c}\text { DWPF Design } \\
\text { Basis Consistency } \\
(\mathbf{c P})^{\dagger} \\
\end{array}$ \\
\hline $\begin{array}{l}\text { SB5 Qual Sample (As- } \\
\text { Received) }\end{array}$ & 5.3 & 1.5 & 7.0 & & NA \\
\hline $\begin{array}{l}\text { SB5 Qual Sample, SRNL } \\
\text { Washed and decanted to } \\
15.9 \mathrm{wt} \% \text { total solids }\end{array}$ & 9.9 & 5.2 & 7.5 & \multirow[b]{2}{*}{$2.5-10$} & \multirow[b]{2}{*}{$4-12$} \\
\hline $\begin{array}{l}\text { SB5 Qual Sample, SRNL } \\
\text { Washed and decanted to } \\
17.1 \mathrm{wt} \% \text { total solids } \\
\text { (SC-6 SRAT Receipt) }\end{array}$ & 11.2 & 6.8 & 8.6 & & \\
\hline $\begin{array}{l}\text { SC-6 SRAT Product (26.5 } \\
\text { wt } \% \text { total solids) }\end{array}$ & 14.9 & 9.9 & 14.3 & \multirow[b]{2}{*}{$1.5-5.0$} & \multirow[b]{2}{*}{$5-12$} \\
\hline $\begin{array}{l}\text { SC-6 SRAT Product (diluted } \\
\text { to } 20 \mathrm{wt} \% \text { total solids } \\
\text { with SRAT cycle } \\
\text { dewater) } \\
\end{array}$ & $11.3^{*}$ & 6.4 & 6.1 & & \\
\hline $\begin{array}{c}\text { SC-6 SME Product (48.8 } \\
\text { wt } \% \text { total solids) }\end{array}$ & 40.4 & 16.7 & 13.8 & $2.5-15$ & $10-40$ \\
\hline
\end{tabular}

This is an estimate. Dewater from the SC-6 SRAT cycle was added back to a portion of an SC-6 SRAT product to produce a sample at $20 \%$ total solids. The total solids were not measured.

$\dagger$ There are no specific design bases for sludge rheology. Design bases for SRAT and SME products can be found in Reference 34. 


\subsection{CONCLUSIONS}

SRNL washed the Tank 51 SB5 qualification sample per LWO plans/projections of April 2008 with the reduction of one wash/decant cycle. Note that sodium content following SRNL's final decant was similar to the sodium projected by the Tank Farm with the additional wash/decant cycle. During washing, settling and decanting were similar to previous sludge batches. SRNL was able to produce a sludge at $11.2 \mathrm{wt} \%$ insoluble solids with rheology acceptable for DWPF processing.

DWPF simulations proceeded using the SRNL washed sample. An acid stoichiometry of 130\% was used for the SRAT cycle. SRAT and SME total solids targets were $25 \mathrm{wt} \%$ and $45 \mathrm{wt} \%$, respectively. The objectives of these simulations were accomplished: nitrite was destroyed; mercury was removed to below $0.45 \mathrm{wt} \%$ total solids in the SRAT product; and DWPF hydrogen generation rates were not exceeded. Peak offgas generation rates during SRAT processing were $0.495 \mathrm{lb} / \mathrm{h}$ for hydrogen, $323 \mathrm{lb} / \mathrm{h}$ for carbon dioxide, and $66.8 \mathrm{lb} / \mathrm{h}$ for nitrous oxide when scaled to a DWPF 6,000 gallon SRAT receipt volume. During SME processing, peak offgas generation rates were $0.148 \mathrm{lb} / \mathrm{h}$ for hydrogen, $45.0 \mathrm{lb} / \mathrm{h}$ for carbon dioxide, and $4.53 \mathrm{lb} / \mathrm{h}$ for nitrous oxide. The Total Organic Carbon content of the SME product slurry was $9,920 \mathrm{mg} / \mathrm{kg}$, which is much less than the DWPF melter flammability limit. There were no issues with heat transfer, water removal, or sample mixing in the SRNL apparatus.

The SRAT product at $26.5 \mathrm{wt} \%$ total solids exceeded the DWPF limit for SRAT product yield stress. A sample adjusted to $20 \mathrm{wt} \%$ total solids had acceptable rheological properties. The SME product yield stress only slightly exceeded DWPF limits at a measured wt $\%$ total solids of 48.8. It is anticipated that rheology would be acceptable at the target of $45 \mathrm{wt} \%$ total solids. Also, DWPF has processed SME products with equivalent yield stress and consistency to the higher solids sample.

During the SRAT cycle, excessive foaming was observed during formic acid addition and during boiling. $100 \mathrm{ppm}$ additions of antifoam were added nearly hourly during boiling to control foaming. It is not clear if foaming was a property of the sludge or due to inferior antifoam based on recent DWPF experience. An adequate assessment of foaming could not be made during the SME cycle because of the small amount of sample. However, the SME slurry was maintained below the upper window of the vessel insulation so foaming was not excessive. A $100 \mathrm{ppm}$ addition of antifoam was added with each decon water and frit/water addition to ensure foaming would not be an issue.

Glass was fabricated from a subsample of SME product. The targeted waste loading was 34 $\mathrm{wt} \%$ waste oxides. The glass was acceptable with respect to chemical durability as measured by the PCT. The PCT response was also predictable by the current durability models of the DWPF PCCS. 


\subsection{RECOMMENDATIONS}

Based on these simulations and the associated SB5 simulant runs with the blend projected to be processed as SB5, SRNL recommends the following:

- A final washed Tank 51 concentration of no more than $11.2 \mathrm{wt} \%$ insoluble solids.

- A SRAT cycle acid stoichiometry of $130 \%$

- SRAT product solids concentration target of $20 \mathrm{wt} \%$ total solids

- SRAT boiling time (dewater plus reflux) of 18 hours at 5,000 lb/hr steam $(90,000 \mathrm{lb}$ of steam total) to ensure $\mathrm{Hg}$ reduction

- SME product concentration of $45 \mathrm{wt} \%$ total solids

- Glass waste loading of $34 \mathrm{wt} \%$ waste oxides using Frit 418 if the Pu limit does not cause a lower value to be targeted

These are initial recommendations and could be adjusted based on DWPF processing of the blend of SB5 with the heel of SB4 since blend studies were not performed with radioactive sludge and the heel is not considered in SRNL studies. It is also recommended that foaming during SB5 processing be carefully observed. Without further testing to evaluate the cause of foaming (a sludge characteristic or inferior antifoam), a specific antifoam addition strategy cannot be recommended at this time. SRNL recommends antifoam testing using a sample of SB5 - Tank 51 in the first quarter of fiscal year 2009 to provide a reasonable antifoam strategy. However, the customer has requested SRNL to evaluate antifoam using a Tank 40 sample (following the SB5 transfer from Tank 51 to Tank 40) early in the second quarter of fiscal year 2009.

As part of SRNL's FY09 testing to support DWPF processing, further chemical and physical characterization of radioactive slurries will be performed to try to better understand the causes for the increased foaminess and yield stress of radioactive sludges compared to the simulants fabricated for testing. SRNL simulant testing will also focus on trying to better represent the properties of aluminum dissolved sludge since aluminum dissolution is anticipated to be performed on most of the HM sludge remaining to be processed through DWPF. 
SRNS-STI-2008-00111, REVISION 0

\subsection{REFERENCES}

1. Davis, B. A. Sludge Batch 5 SRNL Shielded Cells Testing: Technical Task Request; HLWDWPF-TTR-2008-0010; Savannah River Site: Aiken, SC, 2008.

2. Lambert, D. P.; Stone, M. E.; Pickenheim, B. R.; Best, D. R.; Koopman, D. C. Sludge Batch 5 Simulant Flowsheet Studies; SRNS-STI-2008-00024; Savannah River National Lab: Aiken, SC, 2008.

3. Bannochie, C. J.; Pareizs, J. M. Qualification of DWPF Sludge Batch 5 (Macrobatch 6) in the SRNL Shielded Cells: Task Technical \& Quality Assurance Plan; WSRC-RP-2008-00137, Rev. 1; Savannah River National Laboratory: Aiken, SC, 2008.

4. Bannochie, C. J. Qualification of DWPF Sludge Batch 5 in the SRNL Shielded Cells: Analytical Study Plan; WSRCRP-2008-00138, Rev. 2; Savannah River National Laboratory: Aiken, SC, 2008.

5. Eubanks, R. A. H-Canyon Special Waste Compliance Plan for Transfer of PlutoniumBeryllium (HCAN-SW-18) to Tank 51 241-H Tank Farm (U) X-WCP-H-00022, Rev. 0; Westinghouse Savannah River Co.: Aiken, SC, 2008.

6. Bannochie, C. J. Tank 40 Final SB4 Chemical Characterization Results; WSRC-STI-200700674; Savannah River National Laboratory: Aiken, SC, 2008.

7. Pareizs, J. M.; Reboul, S. H.; Bannochie, C. J. SRNL Washed Sludge Batch 5 Qualification Sample Supernatant and Rheology Results; Interoffice Memorandum SRNL-PSE-200800116; Savannah River National Laboratory: Aiken, SC, 2008.

8. Bannochie, C. J.; Ajo, H. M.; Click, D. R.; Pareizs, J. M. Tank 51 SB5 Qualification Sample Elemental Slurry Composition; SRNL-PSE-2008-00087; Savannah River National Laboratory: Aiken, SC, 2008.

9. Bannochie, C. J.; Pareizs, J. M.; Ajo, H. M. Sludge Batch 5 Acceptance Evaluation: Chemical Characterization of the Tank 51 SB5 Qualification Sample Prepared at SRNL; SRNL-PSE-2008-00126; Savannah River National Laboratory: Aiken, SC, 2008.

10. Process Science and Engineering Section Procedure Manual; Manual L29; Savannah River National Lab: Aiken, SC, 2007.

11. Stone, M. E. Lab-Scale CPC Equipment Set-up; SRNL-PSE-2006-00074; Savannah River National Laboratory: Aiken, SC, 2006.

12. Stone, M. E. SRAT Assembly for SB4 Shielded Cells Testing: SC-6; SRNL-PSE-2008-00134; Savannah River National Laboratory: Aiken, SC, 2008.

13. Sludge Batch 5 II; WSRC-NB-2008-00022; Savannah River National Laboratory: Aiken, SC, 2008. 
14. Sludge Batch 5 III; WSRC-NB-00074; Savannah River National Laboratory: Aiken, SC, 2008.

15. Sludge Batch 5 IV; SRNS-NB-2008-00004; Savannah River National Laboratory: Aiken, SC, 2008.

16. Sludge Batch 5 I; WSRC-NB-2008-00021; Savannah River National Laboratory: Aiken, SC, 2008.

17. Lambert, D. P. Acid Calculation Spreadsheet for DWPF Simulations, Revision 1; InterOffice Memorandum SRNL-PSE-2006-00173; Savannah River National Laboratory: Aiken, SC, 2006.

18. Jantzen, C. M.; Zamecnik, J. R.; Koopman, D. C.; Herman, C. C.; Pickett, J. B. Electron Equivalents Model for Controlling Reduction-Oxidation ( REDOX) Equilibrium during High Level Waste (HLW) Vitrification; WSRC-TR-2003-00126; Savannah River National Laboratory: Aiken, SC, 2003.

19. Jantzen, C. M.; Newell, J. D. Defense Waste Processing Facility (DWPF) Sludge Batch 5 (SB5) Redox Validation; SRNL-PSE-2008-00184; Savannah River National Laboratory: Aiken, SC, 2008.

20. Lambert, D. P. Recommendations for SB5 Qualification Processing in the Shielded Cells; SRNL-PSE-2008-00133; Savannah River National Laboratory: Aiken, SC, 2008.

21. Pareizs, J. M.; Bannochie, C. J.; Click, D. R.; Hansen, E. K.; Lambert, D. P.; Stone, M. E. Washing and Demonstration of the DWPF Flowsheet in the SRNL Shielded Cells Using Post Aluminum Dissolution Tank 51 Sludge Slurry; WSRC-sTI-2008-00086; Savannah River National Laboratory: Aiken, SC, 2008.

22. Pareizs, J. M.; Bannochie, C. J.; Barnes, M. J.; Bibler, N. E.; Click, D. R.; Hansen, E. K.; Lambert, D. P.; Stone, M. E. Demonstration of the DWPF Flowsheet in the SRNL Shielded Cells in Support of Sludge Batch 4 Qualification; WSRC-STI-2007-00053; Savannah River National Laboratory: Aiken, SC, 2007.

23. Stone, M. E. SC-6 SME Cycle Supplemental Parameters and Data; SRNL-PSE-2008-00160; Savannah River National Laboratory: Aiken, SC, 2008.

24. Fox, K. M.; Edwards, T. B.; Peeler, D. K. Recommended Frit Composition for the SB5 Qualification Demonstration; SRNL-PSE-2008-00164; Savannah River National Laboratory: Aiken, SC, 2008.

25. Standard Test Methods for Determining Chemical Durability of Nuclear, Hazardous, and Mixed Waste Glasses and Multiphase Glass Ceramics: The Product Consistency Test (PCT); ASTM Standard C 1285-02; American Society for Testing and Materials (ASTM): West Conshohocken, PA, 2007. 
26. Management, O. o. E. Waste Acceptance Product Specification for Vitrified High-LevelWaste Forms; USDOE Document DOE/EM-0093, Rev. 2; 1996.

27. Jantzen, C. M.; Bibler, N. E.; Beam, D. C.; Crawford, C. L.; Pickett, M. A. Characterization of the Defense Waste Processing Facility (DWPF) Environmental Assessment (EA) Glass Standard Reference Material; WSRC-TR-92-346; Savannah River National Laboratory: Aiken, SC, 1994.

28. Youchak-Billings, A. L.; Bibler, N. E.; Edwards, T. B.; Stone, M. E.; Fox, K. M.; Click, D. R.; Lambert, D. P.; Bannochie, C. J. Results of the Tank 51 SB5 Qualification SME Cycle and Glass Fabrication; SRNL-PSE-2008-00186; Savannah River National Laboratory: Aiken, SC, 2008.

29. Brown, K. G.; Postles, R. L.; Edwards, T. B. SME Acceptability Determination for DWPF Process Control (U); WSRC-TR-95-00364, Rev. 5; Savannah River National Laboratory: Aiken, SC, 2006.

30. Edwards, T. B.; Peeler, D. K.; Fox, K. M. The Nepheline Discriminator: Justification and DWPF PCCS Implementation Details; WSRC-STI-2006-00014; Savannah River National Laboratory: Aiken, SC, 2006.

31. Bibler, N. E.; Bannochie, C. J.; Ray, J. W. Characterization of Radioactive Macrobatch 4 Glass Being Produced by the Defense Waste Processing Facility at the Savannah River Site; Paper 6249 in Session 27, WM Symposium 06 Proceedings; Tuscon, AZ, 2006.

32. Bibler, N. E.; Pareizs, J. M.; Edwards, T. B.; Coleman, C. J.; Crawford, C. L. Qualification of a Radioactive High Aluminum Glass for Processing in the Defense Waste Processing Facility at the Savannah River Site; Paper 8410 in Session 41, WM Symposium 08 Proceedings; Tucson, AZ, 2008.

33. Darby, R., Chemical Engineering Fluid Mechanics, 2nd edition. Marcel Dekker: 2001.

34. Technical Data Summary For the Defense Waste Processing Facility, Part 10; DPSTD-8038-2; Savannah River Site: Aiken, SC, 1982. 


\subsection{ACKNOWLEDGEMENTS}

The authors would like to recognize the invaluable support of the SRNL Shielded Cells technicians and management for the in-cells work; the ACTL technicians for assistance in equipment setup, reagent preparation, and consultation during the SRAT and SME cycles; S. L. Crump for sludge SVOA and VOA analyses; SRNL-AD researchers and technicians for all other analyses; T. B. Edwards of the SRNL Statistical Consultation group for statistical analysis support; and the SRNL Glass Shop for providing glassware and other miscellaneous hardware. 


\section{APPENDIX A. SETTLING DATA DURING SB5 QUALIFICATION WASHING}

NOTE:

Overall Volume $(m L)=$ Sludge Level $\times 178-150$

\begin{tabular}{|c|c|c|c|c|c|c|c|}
\hline As-Received & & & & & & & \\
\hline & Initial level & 145 & Sludae Slı & rrv Volume & 2431 & $\mathrm{ml}$ & \\
\hline & & & & & & & \\
\hline Date/Time & $\begin{array}{l}\text { Settling } \\
\text { Time (d) }\end{array}$ & $\begin{array}{c}\text { Sludge } \\
\text { Level }\end{array}$ & $\begin{array}{c}\text { Sludge } \\
\text { Volume } \\
(\mathrm{mL})\end{array}$ & $\begin{array}{c}\text { Supernate } \\
\text { vol }(\mathrm{mL})\end{array}$ & $\begin{array}{c}\text { Sup vol } \\
\text { change } \\
(\mathrm{mL} / \mathrm{d})\end{array}$ & $\begin{array}{l}\text { Ht change } \\
(\mathrm{cm} / \mathrm{d})\end{array}$ & Rel sl ht \\
\hline 3/25/2008 14:15 & 0.0 & 14.5 & 2,431 & 0 & & & 1 \\
\hline 3/26/2008 5:00 & 0.6 & 14 & 2,342 & 89 & 145 & -0.8 & 0.97 \\
\hline 3/26/2008 15:10 & 1.0 & 13.7 & 2,289 & 142 & 126 & -0.7 & 0.94 \\
\hline $3 / 27 / 20085: 20$ & 1.6 & 13.2 & 2,200 & 231 & 151 & -0.8 & 0.91 \\
\hline 3/27/2008 16:00 & 2.1 & 12.8 & 2,128 & 303 & 160 & -0.9 & 0.88 \\
\hline $3 / 28 / 2008$ 17:40 & 3.1 & 11.9 & 1,968 & 463 & 150 & -0.8 & 0.82 \\
\hline $3 / 31 / 20085: 45$ & 5.6 & 10.1 & 1,648 & 783 & 128 & -0.7 & 0.70 \\
\hline 3/31/2008 15:55 & 6.1 & 9.9 & 1,612 & 819 & 84 & -0.5 & 0.68 \\
\hline 4/1/2008 5:30 & 6.6 & 9.6 & 1,559 & 872 & 94 & -0.5 & 0.66 \\
\hline $4 / 1 / 200814: 00$ & 7.0 & 9.5 & 1,541 & 890 & 50 & -0.3 & 0.66 \\
\hline $4 / 2 / 20086: 10$ & 7.7 & 9.2 & 1,488 & 943 & 79 & -0.4 & 0.63 \\
\hline $4 / 2 / 200815: 15$ & 8.0 & 9.05 & 1,461 & 970 & 71 & -0.4 & 0.62 \\
\hline $4 / 3 / 2008$ 5:00 & 8.6 & 8.9 & 1,434 & 997 & 47 & -0.3 & 0.61 \\
\hline $4 / 3 / 200815: 00$ & 9.0 & 8.8 & 1,416 & 1,015 & 43 & -0.2 & 0.61 \\
\hline $4 / 4 / 20086: 40$ & 9.7 & 8.7 & 1,399 & 1,032 & 27 & -0.2 & 0.60 \\
\hline $4 / 4 / 2008$ 15:30 & 10.1 & 8.5 & 1,363 & 1,068 & 97 & -0.5 & 0.59 \\
\hline 4/7/2008 6:30 & 12.7 & 8.4 & 1,345 & 1,086 & 7 & 0.0 & 0.58 \\
\hline $4 / 7 / 2008$ 14:45 & 13.0 & 8.35 & 1,336 & 1,095 & 26 & -0.1 & 0.58 \\
\hline $4 / 8 / 20086: 45$ & 13.7 & 8.30 & 1,327 & 1,104 & 13 & -0.1 & 0.57 \\
\hline 4/9/2008 8:30 & 14.8 & 8.30 & 1,327 & 1,104 & 0 & 0.0 & 0.57 \\
\hline 4/9/2008 16:30 & 15.1 & 8.30 & 1,327 & 1,104 & 0 & 0.0 & 0.57 \\
\hline 4/10/2008 6:15 & 15.7 & 8.25 & 1,319 & 1,113 & 16 & -0.1 & 0.57 \\
\hline 4/10/2008 15:20 & 16.0 & 8.20 & 1,310 & 1,121 & 24 & -0.1 & 0.57 \\
\hline 4/14/2008 7:20 & 19.7 & 8.20 & 1,310 & 1,121 & 0 & 0.0 & 0.57 \\
\hline 4/14/2008 15:45 & 20.1 & 8.10 & 1,292 & 1,139 & 51 & -0.3 & 0.56 \\
\hline 4/15/2008 8:00 & 20.7 & 8.10 & 1,292 & 1,139 & 0 & 0.0 & 0.56 \\
\hline 4/15/2008 15:00 & 21.0 & 8.10 & 1,292 & 1,139 & 0 & 0.0 & 0.56 \\
\hline 4/16/2008 7:00 & 21.7 & 8.10 & 1,292 & 1,139 & 0 & 0.0 & 0.56 \\
\hline 4/16/2008 8:40 & 21.8 & 8.00 & 1,274 & 1,157 & 256 & -1.4 & 0.55 \\
\hline 4/16/2008 15:10 & 22.0 & 8.00 & 1,274 & 1,157 & 0 & 0.0 & 0.55 \\
\hline $4 / 17 / 20086: 20$ & 22.7 & 7.60 & 1,203 & 1,228 & 113 & -0.6 & 0.52 \\
\hline
\end{tabular}




\begin{tabular}{|c|c|c|c|c|c|c|c|}
\hline \multicolumn{8}{|l|}{ Wash B } \\
\hline & Initial level & 13.5 & \multicolumn{2}{|c|}{ Sludge Slurry Volume } & 2253 & $\mathrm{~mL}$ & \\
\hline & & & & & & & \\
\hline Date/Time & $\begin{array}{l}\text { Settling } \\
\text { Time (d) }\end{array}$ & $\begin{array}{l}\text { Sludge } \\
\text { Level }\end{array}$ & $\begin{array}{c}\text { Sludge } \\
\text { Volume } \\
\text { (mL) }\end{array}$ & $\begin{array}{c}\text { Supernate } \\
\text { vol }(\mathrm{mL})\end{array}$ & $\begin{array}{l}\text { Sup vol } \\
\text { change } \\
(\mathrm{mL} / \mathrm{d})\end{array}$ & $\begin{array}{l}\text { Ht change } \\
(\mathrm{cm} / \mathrm{d})\end{array}$ & Rel sl ht \\
\hline 4/18/2008 13:00 & 0.0 & 13.5 & 2,253 & 0 & & & 1 \\
\hline 4/21/2008 7:00 & 2.8 & 10.65 & 1,746 & 507 & 184 & -1.0 & 0.79 \\
\hline 4/21/2008 16:00 & 3.1 & 10.3 & 1,683 & 570 & 166 & -0.9 & 0.76 \\
\hline 4/22/2008 7:00 & 3.8 & 9.8 & 1,594 & 659 & 142 & -0.8 & 0.73 \\
\hline 4/23/2008 7:00 & 4.8 & 9.2 & 1,488 & 765 & 107 & -0.6 & 0.68 \\
\hline 4/23/2008 16:30 & 5.1 & 9.1 & 1,470 & 783 & 45 & -0.3 & 0.67 \\
\hline 4/24/2008 7:00 & 5.8 & 8.8 & 1,416 & 837 & 88 & -0.5 & 0.65 \\
\hline
\end{tabular}

\begin{tabular}{|c|c|c|c|c|c|c|}
\hline Wash 1 & & & & & & \\
\hline Sludge Slurry Level & & 14.6 & Sludge Slu & y Volume $(\mathrm{r}$ & 2440.6 & $\mathrm{~mL}$ \\
\hline & & & & & & \\
\hline Date/Time & $\begin{array}{l}\text { Settling } \\
\text { Time (d) }\end{array}$ & $\begin{array}{c}\text { Sludge } \\
\text { Level }\end{array}$ & $\begin{array}{c}\text { Sludge } \\
\text { Volume } \\
(\mathrm{mL})\end{array}$ & $\begin{array}{c}\text { Supernate } \\
\text { vol }(m L)\end{array}$ & $\begin{array}{l}\text { Sup vol } \\
\text { change } \\
(\mathrm{mL} / \mathrm{d})\end{array}$ & $\begin{array}{c}\text { Rel sludge } \\
\text { ht }\end{array}$ \\
\hline 10/16/2007 14:45 & 0.0 & 14.6 & 2,441 & 0 & & 1.00 \\
\hline $10 / 17 / 20076: 40$ & 0.7 & 13.4 & 2,229 & 211 & 318 & 0.92 \\
\hline $10 / 17 / 2007$ 15:00 & 1.0 & 13.0 & 2,159 & 282 & 203 & 0.89 \\
\hline 10/18/2007 7:15 & 1.7 & 12.7 & 2,106 & 334 & 78 & 0.87 \\
\hline $10 / 18 / 2007$ 14:20 & 2.0 & 12.3 & 2,036 & 405 & 239 & 0.84 \\
\hline 10/19/2007 6:10 & 2.6 & 11.5 & 1,895 & 546 & 213 & 0.79 \\
\hline $10 / 19 / 2007$ 10:25 & 2.8 & 11.2 & 1,842 & 598 & 298 & 0.77 \\
\hline $10 / 22 / 20076: 40$ & 5.7 & 9.4 & 1,525 & 915 & 111 & 0.64 \\
\hline 10/22/2007 15:30 & 6.0 & 9.3 & 1,508 & 933 & 48 & 0.64 \\
\hline $10 / 23 / 20077: 35$ & 6.7 & 9.0 & 1,455 & 986 & 79 & 0.62 \\
\hline $10 / 23 / 2007$ 13:40 & 7.0 & 9.0 & 1,455 & 986 & 0 & 0.62 \\
\hline 10/24/2007 6:40 & 7.7 & 8.8 & 1,420 & 1,021 & 50 & 0.60 \\
\hline $10 / 25 / 2007$ 10:35 & 8.8 & 8.6 & 1,385 & 1,056 & 30 & 0.59 \\
\hline $10 / 29 / 20077: 48$ & 12.7 & 8.5 & 1,367 & 1,074 & 5 & 0.58 \\
\hline 10/30/2007 14:00 & 14.0 & 8.1 & 1,297 & 1,144 & 56 & 0.55 \\
\hline 10/31/2007 7:55 & 14.7 & 8.0 & 1,279 & 1,162 & 24 & 0.55 \\
\hline
\end{tabular}


SRNS-STI-2008-00111, REVISION 0

\begin{tabular}{|c|c|c|c|c|c|c|}
\hline \multicolumn{7}{|l|}{ Wash 2} \\
\hline \multicolumn{2}{|l|}{ Sludge Slurry Level } & 14.8 & \multicolumn{2}{|c|}{ Sludge Slurry Volume } & 2475.8 & $\mathrm{~mL}$ \\
\hline Date/Time & $\begin{array}{l}\text { Settling Time } \\
\text { (d) }\end{array}$ & $\begin{array}{l}\text { Sludge } \\
\text { Level }\end{array}$ & $\begin{array}{c}\text { Sludge } \\
\text { Volume } \\
(\mathrm{mL})\end{array}$ & $\begin{array}{c}\text { Supernate } \\
\text { vol }(\mathrm{mL})\end{array}$ & $\begin{array}{l}\text { Sup vol } \\
\text { change } \\
(\mathrm{mL} / \mathrm{d})\end{array}$ & $\begin{array}{c}\text { Rel sludge } \\
\text { ht }\end{array}$ \\
\hline 11/6/2007 13:30 & 0.0 & 14.8 & 2,476 & 0 & & 1 \\
\hline $11 / 6 / 200715: 45$ & 0.1 & 14.7 & 2,458 & 18 & 188 & 0.99 \\
\hline 11/7/2007 15:40 & 1.1 & 8.7 & 1,402 & 1,074 & 1060 & 0.59 \\
\hline 11/8/2007 6:40 & 1.7 & 8.4 & 1,349 & 1,126 & 84 & 0.57 \\
\hline 11/8/2007 15:00 & 2.1 & 8.2 & 1,314 & 1,162 & 101 & 0.55 \\
\hline 11/9/2007 11:15 & 2.9 & 7.9 & 1,261 & 1,214 & 63 & 0.53 \\
\hline 11/12/2007 6:35 & 5.7 & 7.8 & 1,244 & 1,232 & 19 & 0.53 \\
\hline 11/12/2007 16:15 & 6.1 & 7.8 & 1,244 & 1,232 & 0 & 0.53 \\
\hline 11/13/2007 6:40 & 6.7 & 7.8 & 1,244 & 1,232 & 0 & 0.53 \\
\hline
\end{tabular}


APPENDIX B. SUPPLEMENTAL PCT DATA

Table B-1. Parameters Prescribed in ASTM-1285-02 Procedure for Successful Performance of a Product Consistency Test using Test Method A

\begin{tabular}{|l|c|c|}
\hline \multicolumn{1}{|c|}{ Parameter } & Prescribed Value & Measured Value \\
\hline Resistivity of Water & $>18 \mathrm{M} \Omega \mathrm{cm}$ & 18.2 at $23^{\circ} \mathrm{C}$ \\
\hline Vol. Leachant/Mass Glass & $10 \pm 0.5 \mathrm{~mL} / \mathrm{g}$ & $9.98-10.01$ \\
\hline Temperature of Oven & $90 \pm 2^{\circ} \mathrm{C}$ & $90.5-91.1^{\circ} \mathrm{C}$ \\
\hline Time in Oven & $168.0 \pm 3.4$ hours & $<0.4$ hours \\
\hline Leachant loss during test & $12.9-22.7 \mathrm{ppm}$ & $16.3-17.7 \mathrm{ppm}(\mathrm{c})$ \\
\hline $\begin{array}{l}\text { Control Chart Conc. for } \\
\text { Leaching B from Std. ARM } \\
\text { Glass (b) }\end{array}$ & & $12.8-13.7 \mathrm{ppm}(\mathrm{c})$ \\
\hline $\begin{array}{l}\text { Control Chart Conc. for } \\
\text { Leaching Li from Std. } \\
\text { ARM Glass (b) }\end{array}$ & $10.8-16.3 \mathrm{ppm}$ & $34.6-37.0 \mathrm{ppm}$ (c) \\
\hline $\begin{array}{l}\text { Control Chart Conc. for } \\
\text { Leaching Na from Std. } \\
\text { ARM Glass (b) }\end{array}$ & $28.9-43.6 \mathrm{ppm}$ & $60.5-63.5 \mathrm{ppm}$ (c) \\
\hline $\begin{array}{l}\text { Control Chart Conc. for } \\
\text { Leaching Si from Std. ARM } \\
\text { Glass (b) }\end{array}$ & $49.0-73.4 \mathrm{ppm}$ & \\
\hline
\end{tabular}

"Standard Test Methods for Determining Chemical Durability of Nuclear, Hazardous, and Mixed Waste Glasses and Multiphase Glass Ceramics: The Product Consistency Test (PCT)," ASTM Standard C 1285-02, Annual Book of ASTM Standards, Section 12, Volume 12.01, pp. 648-670, American Society for Testing and Materials (ASTM), West Conshohocken, PA (2007).

(b) C.M. Jantzen, N.E. Bibler, D.C. Beam, C.L. Crawford, and M.A. Pickett, "Characterization of the Defense Waste Processing Facility (DWPF) Environmental Assessment (EA) Glass Standard Reference Material," WSRCTR-92-346, Savannah River Site, Aiken, SC, 1994.

(c) Range for leaching triplicate samples for Standard ARM glass. 
Table B-2. Requirements Prescribed in ASTM-1285-02 Procedure for Analytical Results of Multielement Standard and Blanks in Product Consistency Test using Test Method A

\begin{tabular}{|c|c|c|}
\hline Analytical Result & Prescribed Value & Measured Value \\
\hline $\begin{array}{c}\text { Relative Standard Deviation } \\
\text { of Triplicate Results of } \\
\text { Multielement Standard }\end{array}$ & $<10 \%$ & $<1.9 \%$ \\
\hline $\begin{array}{c}\text { Agreement of Measured } \\
\text { Average with Reported } \\
\text { Concentrations in } \\
\text { Multielement Standard }\end{array}$ & Within $10 \%$ & Within $5 \%$ \\
\hline Concentrations in the & $<10 \%$ of Concentrations \\
Blanks & $\begin{array}{c}\text { Concentrations of B, Li, Na, } \\
\text { and Si in Triplicate Blanks } \\
<0.7 \% \text { of Concentrations in } \\
\text { Leachate. }\end{array}$ \\
\hline
\end{tabular}




\section{APPENDIX C. RHEOLOGICAL CHARTS AND FLOW CURVES}

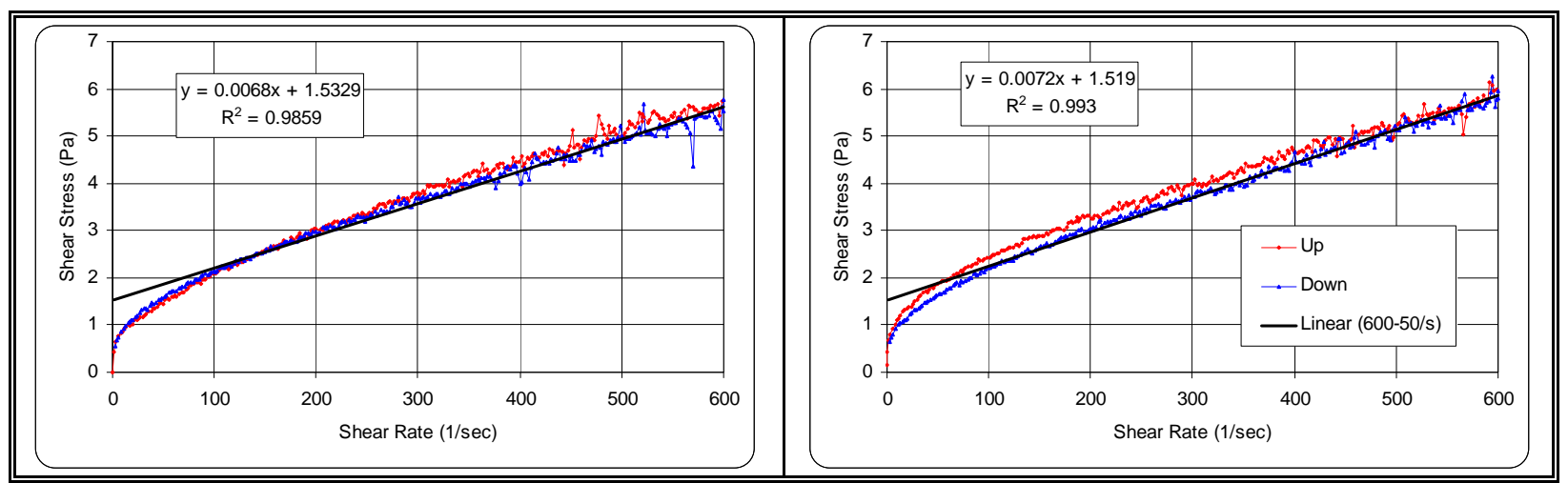

Figure C-1. Tank 51 SB5 Qual Sample, As-Received, May 2007, Flow Curve

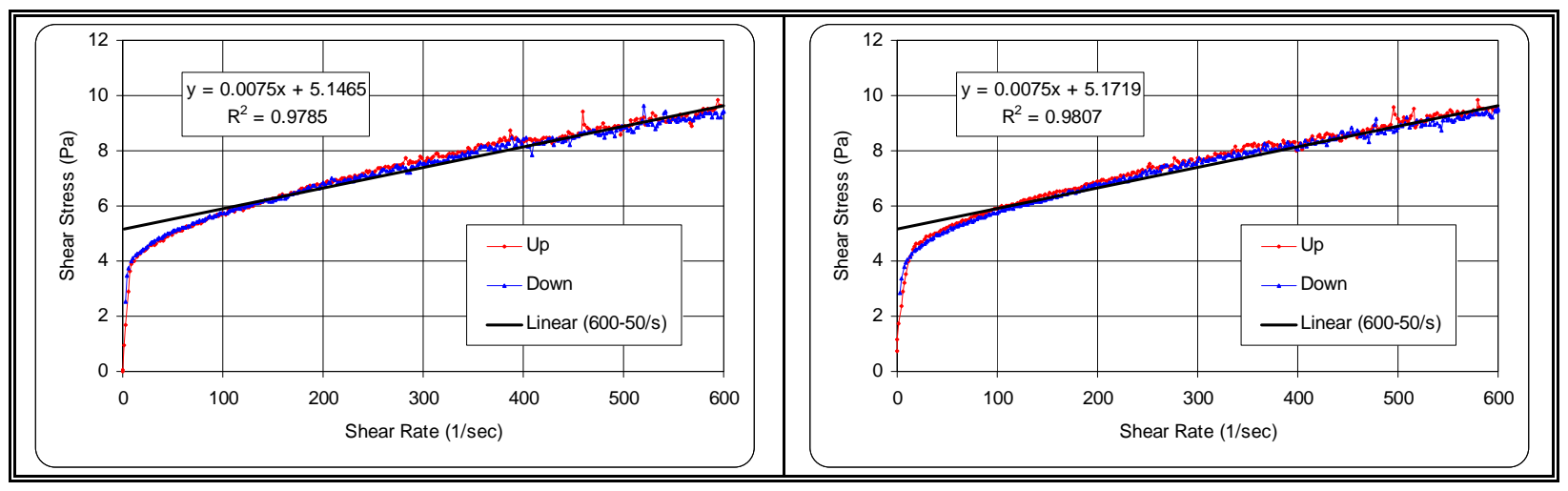

Figure C-2. Tank 51, SB5 Qual Sample SRNL Washed and Decanted to 15.9 wt\% Total Solids, Flow Curves

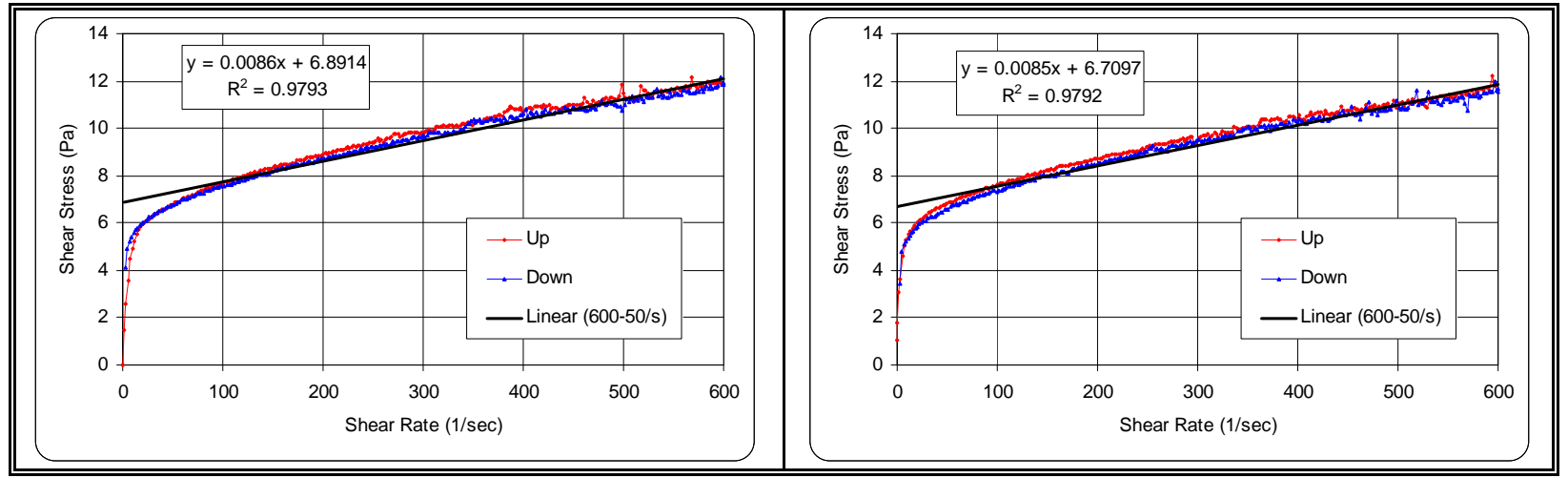

Figure C-3. Tank 51, SB5 Qual Sample SRNL Washed and Decanted to $17.1 \mathrm{wt} \%$ Total Solids (SC-6 SRAT Receipt), Flow Curves 

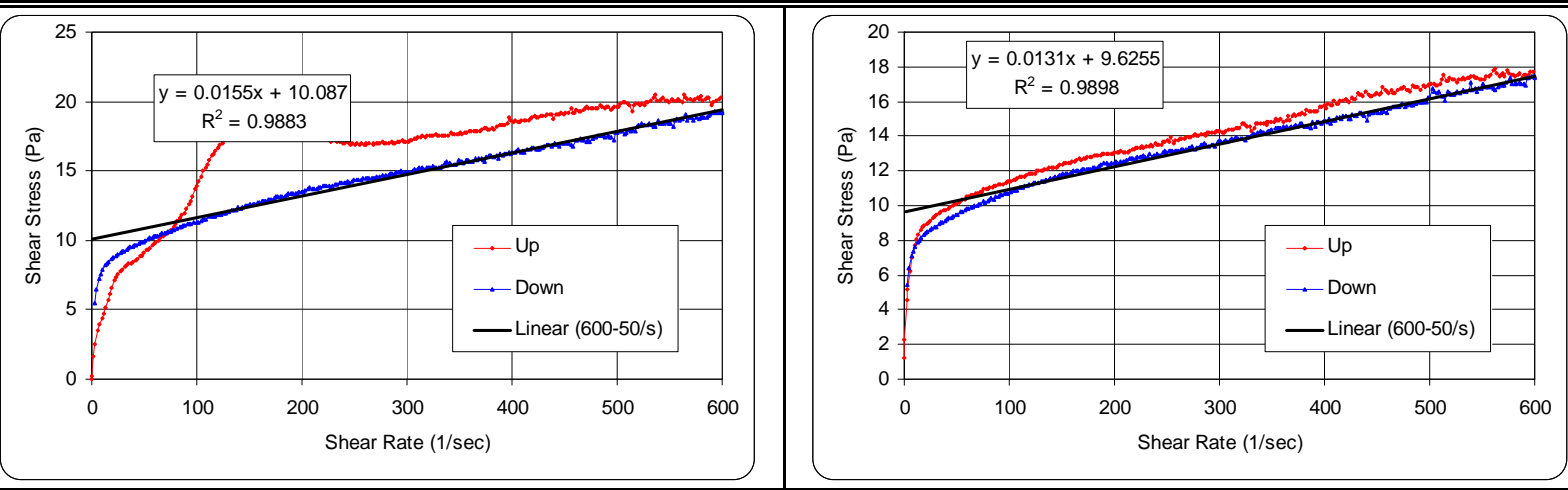

Figure C-4. SRNL SC-6 SRAT Product at 26.5 wt\% Total Solids, Flow Curves

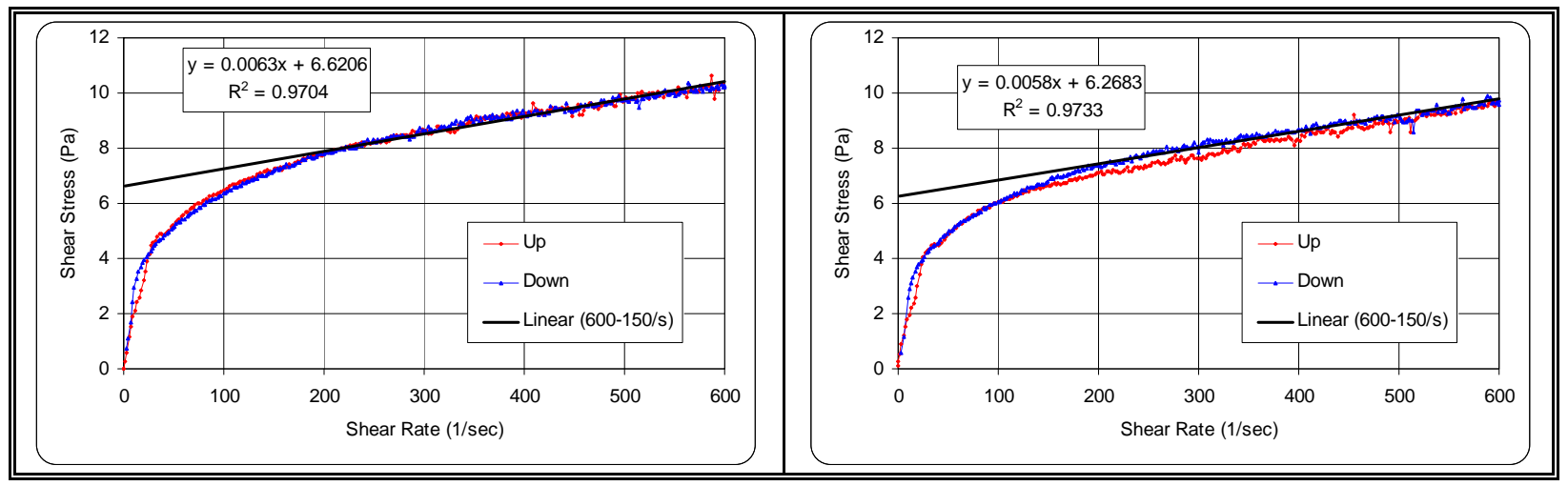

Figure C-5. SRNL SC-6 SRAT Product at 20 wt\% Total Solids, Flow Curves

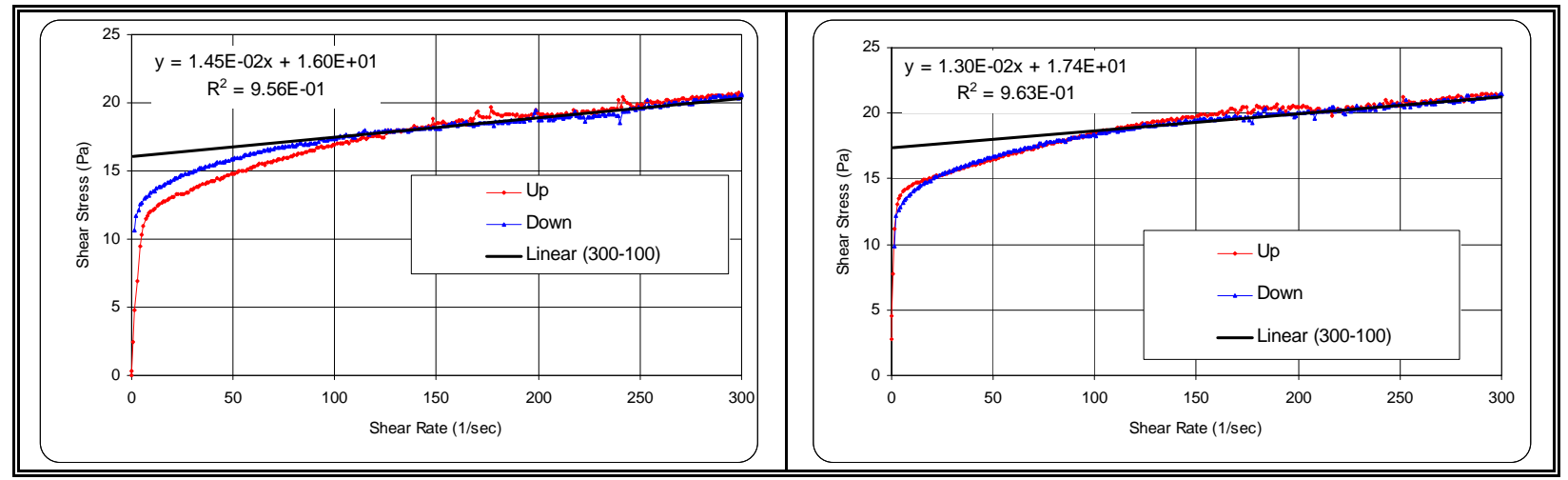

Figure C-6. SRNL SC-6 SME Product, Flow Curves 


\section{APPENDIX D. SC-6 PROCESSING MASS BALANCE AND ANION CONVERSION/DESTRUCTION CALCULATIONS}

\begin{tabular}{|c|c|c|}
\hline & Units & SC-6 \\
\hline \multicolumn{3}{|l|}{ SRAT Cycle Balance } \\
\hline SRAT Inputs & & \\
\hline SRAT Receipt & grams & 1073.03 \\
\hline Rinse and MWWT Water & grams & 139.58 \\
\hline SRAT Antifoam (and water) & grams & 61.36 \\
\hline Nitric Acid solution & grams & 30.55 \\
\hline Formic Acid solution & grams & 69.96 \\
\hline $\begin{array}{r}\text { Water added to flush Nitric and Formic Acid } \\
\text { Lines }\end{array}$ & grams & 20 \\
\hline \multicolumn{3}{|l|}{ SRAT Outputs } \\
\hline Total Dewater & grams & 453.7 \\
\hline MWWT Dewater mass & grams & 32.274 \\
\hline Cold Finger mass & grams & 22.22 \\
\hline SRAT Sample & grams & 308 \\
\hline SRAT Product Mass & grams & 578.286 \\
\hline & & \\
\hline \multicolumn{3}{|l|}{ SME Mass Balance } \\
\hline \multicolumn{3}{|l|}{ SME Cycle Inputs } \\
\hline SRAT Product Mass to SME cycle & grams & 578.286 \\
\hline Canister Water Addition & grams & 717.5 \\
\hline SME Antifoam Solution Addition & grams & 7.28 \\
\hline $\begin{array}{ll} & \text { Frit \#1 } \\
\end{array}$ & grams & 91.39 \\
\hline Frit Water \#1 & grams & 90.02 \\
\hline Formic Acid \#1 & grams & 1.37 \\
\hline Frit \#2 & grams & 91.39 \\
\hline Frit Water \#2 & grams & 90.02 \\
\hline Formic Acid \#2 & grams & 1.37 \\
\hline \multicolumn{3}{|l|}{ SME Cycle Outputs } \\
\hline Total SME Dewater & grams & 891.07 \\
\hline SME Product Sample & grams & \\
\hline SME Product Mass & grams & 777.56 \\
\hline & & \\
\hline Anion Conversion Balance (SRAT Cycle) & & \\
\hline SRAT Receipt Formate & $\mathrm{mg} / \mathrm{kg}$ & 0 \\
\hline
\end{tabular}




\begin{tabular}{|c|c|c|}
\hline & Units & SC-6 \\
\hline SRAT Receipt Nitrite & $\mathrm{mg} / \mathrm{kg}$ & 8660 \\
\hline SRAT Receipt Nitrate & $\mathrm{mg} / \mathrm{kg}$ & 6220 \\
\hline Formate in SRAT Receipt & grams & \\
\hline Nitrite in SRAT Receipt & grams & 9.292 \\
\hline Nitrate in SRAT Receipt & grams & 6.674 \\
\hline SRAT Formate Added as acid & grams & 61.720 \\
\hline SRAT Nitrate Added as acid & grams & 15.190 \\
\hline SRAT Product Formate & $\mathrm{mg} / \mathrm{kg}$ & 57430 \\
\hline SRAT Product Nitrite & $\mathrm{mg} / \mathrm{kg}$ & $<800$ \\
\hline SRAT Product Nitrate & $\mathrm{mg} / \mathrm{kg}$ & 39090 \\
\hline Formate in SRAT product & grams & 50.899 \\
\hline Nitrite in SRAT product & grams & 0.000 \\
\hline Nitrate in SRAT product & grams & 34.645 \\
\hline SRAT Formate Destruction & grams & 10.821 \\
\hline SRAT Formate Destruction & $\%$ & 17.5 \\
\hline SRAT Nitrite Destruction & grams & $>8.583$ \\
\hline SRAT Nitrite Destruction & $\%$ & $>92$ \\
\hline Nitrate Created in SRAT Cycle & grams & 12.781 \\
\hline Moles of nitrate Created & moles & 0.206 \\
\hline Moles of nitrite reacted & moles & $>0.187$ \\
\hline$\%$ nitrite conversion to nitrate & $\%$ & 110.5 \\
\hline \multicolumn{3}{|l|}{ Anion Conversion Balance (SME Cycle) } \\
\hline SME Product Formate & $\mathrm{mg} / \mathrm{kg}$ & 31,000 \\
\hline SME Product Nitrite & $\mathrm{mg} / \mathrm{kg}$ & 0 \\
\hline SME Product Nitrate & $\mathrm{mg} / \mathrm{kg}$ & 21,400 \\
\hline Formate in SME Feed & grams & 33.211 \\
\hline Nitrate in SME Feed & grams & 22.605 \\
\hline SME Formate Added as acid & grams & 2.41 \\
\hline Formate in SME product & grams & 24.104 \\
\hline Nitrate in SME product & grams & 16.640 \\
\hline SME Formate Destruction & grams & 11.517 \\
\hline SME Formate Destruction & $\%$ & 32.3 \\
\hline SME Nitrate Destruction & grams & 5.966 \\
\hline SME Nitrate Destruction & $\%$ & 26.4 \\
\hline
\end{tabular}




\section{APPENDIX E. CALCULATION OF SOLUBLE AND INSOLUBLE ALUMINUM AND SODIUM BASED ON 100 GRAMS OF IRON}

Calculation Inputs

\begin{tabular}{|c|c|c|c|}
\hline & A & $\mathrm{B}$ & $\mathrm{C}$ \\
\hline 1 & & As-Received Tank 51 & After Washing \\
\hline 2 & Fe $\%$ of total solids & 6.91 & 16.3 \\
\hline 3 & Al \% of total solids & 6.18 & 8.91 \\
\hline 4 & $\mathrm{Na} \%$ of total solids & 32 & 15.2 \\
\hline 5 & Al mg/kg supernatant & 7339 & 1859 \\
\hline 6 & Na mg/kg supernatant & 76352 & 24726 \\
\hline 7 & Wt\% Insoluble solids & 0.0531 & 0.112 \\
\hline 8 & Wt $\%$ Total solids & 0.236 & 0.171 \\
\hline 9 & & & \\
\hline 10 & Given $100 \mathrm{~g}$ Fe (inert, not was & & \\
\hline 11 & Total Al g & $=100 / \mathrm{B} \$ 2 * \mathrm{~B} 3$ & $=100 / C \$ 2 * C 3$ \\
\hline 12 & Total Na g & $=100 / \mathrm{B} \$ 2 * \mathrm{~B} 4$ & $=100 / C \$ 2 * C 4$ \\
\hline 13 & Soluble Al g & $=100 / \mathrm{B} \$ 2 / \mathrm{B} \$ 8 *(1-\mathrm{B} \$ 7) \star \mathrm{B} 5 / 10000$ & $=100 / C \$ 2 / C \$ 8^{*}(1-C \$ 7)^{\star} \mathrm{C} 5 / 10000$ \\
\hline 14 & Soluble Na g & $=100 / \mathrm{B} \$ 2 / \mathrm{B} \$ 8 *(1-\mathrm{B} \$ 7) * \mathrm{~B} 6 / 10000$ & $=100 / C \$ 2 / C \$ 8^{*}(1-\mathrm{C} \$ 7)^{\star} \mathrm{C} 6 / 10000$ \\
\hline 15 & Insoluble Al g & $=\mathrm{B} 11-\mathrm{B} 13$ & $=\mathrm{C} 11-\mathrm{C} 13$ \\
\hline 16 & Insoluble $\mathrm{Na} \mathrm{g}$ & $=\mathrm{B} 12-\mathrm{B} 14$ & $=\mathrm{C} 12-\mathrm{C} 14$ \\
\hline 17 & $\%$ soluble $\mathrm{Al}$ & $=\mathrm{B} 13 / \mathrm{B} 11$ & $=\mathrm{C} 13 / \mathrm{C} 11$ \\
\hline 18 & $\%$ soluble $\mathrm{Na}$ & $=\mathrm{B} 14 / \mathrm{B} 12$ & $=\mathrm{C} 14 / \mathrm{C} 12$ \\
\hline 19 & & & \\
\hline 20 & \% Al Removed & & $=(\mathrm{B} 11-\mathrm{C} 11) / \mathrm{B} 11$ \\
\hline 21 & $\%$ change in insol $\mathrm{Na}$ & & $=(\mathrm{C} 15-\mathrm{B} 15) / \mathrm{B} 15$ \\
\hline 22 & $\%$ change in insol $\mathrm{Al}$ & & $=(\mathrm{C} 16-\mathrm{B} 16) / \mathrm{B} 16$ \\
\hline 23 & $\% \mathrm{Na}$ remaining (rel to init) & & $=(\mathrm{C} 12 / \mathrm{B} 12)$ \\
\hline
\end{tabular}


SRNS-STI-2008-00111, REVISION 0

Calculation Outputs

\begin{tabular}{|r|r|c|c|}
\hline & A & B & C \\
\hline 1 & Fe \% of total solids & $\begin{array}{c}\text { As-Received } \\
\text { Tank 51 }\end{array}$ & $\begin{array}{c}\text { After } \\
\text { Washing }\end{array}$ \\
\hline 2 & Al \% of total solids & 6.18 & 16.3 \\
\hline 3 & Na \% of total solids & 32.0 & 8.91 \\
\hline 4 & Al mg/kg supernatant & 7,339 & 15.2 \\
\hline 5 & Na mg/kg supernatant & 76,352 & 24,726 \\
\hline 6 & Wt\% Insoluble solids & $5.31 \%$ & $11.2 \%$ \\
\hline 7 & Wt\% Total solids & $23.6 \%$ & $17.1 \%$ \\
\hline 8 & & & \\
\hline 9 & Total Al g & 89 & 55 \\
\hline 10 & Given 100 g Fe (inert, not washed out) & \\
\hline 11 & Total Na g & 463 & 93 \\
\hline 12 & Soluble Al g & 43 & 6 \\
\hline 13 & Soluble Na g & 443 & 79 \\
\hline 14 & Insoluble Al g & 47 & 49 \\
\hline 15 & Insoluble Na g & 20 & 14 \\
\hline 16 & $\%$ soluble Al & $48 \%$ & $11 \%$ \\
\hline 17 & $\%$ soluble Na & $96 \%$ & $84 \%$ \\
\hline 18 & \% Al Removed & & $39 \%$ \\
\hline 19 & $\%$ change in insol Na & & $4 \%$ \\
\hline 20 & $\%$ change in insol Al & & $27 \%)$ \\
\hline 21 & & & \\
\hline 22 & $\%$ Na remaining (rel to init) & & \\
\hline 23 & & & \\
\hline
\end{tabular}




\section{Distribution:}

J.E. Marra, 773-A

J.C. Griffin, 773-A

A.B. Barnes, 999-W

D.A. Crowley, 999-W

S.D. Fink, 773-A

B.J. Giddings, 786-1A

C.C. Herman, 999-W

D.J. McCabe, 773-42A

F.M. Pennebaker, 773-A

C.J. Bannochie, 773-42A

M.J. Barnes, 773-A

N.E. Bibler, 773-A

A.L. Billings, 999-W

J.M. Bricker, 704-27S

L.M. Chandler, 773-A

D.R. Click, 773-A

L.H. Connelly, 704-28S

B.A. Davis, 704-27S

H.H. Elder, 704-30S

T.B. Edwards, 999-W

T.L. Fellinger, 704-28S

K.M. Fox, 999-W

J.M. Gillam, 766-H

B.A. Hamm, 766-H

E.W. Holtzscheiter, 704-15S

J.F. Iaukea, 704-30S

C.M. Jantzen, 773-A

M.T. Keefer, 766-H

D.C. Koopman, 999-W

D.P. Lambert, 999-W

R.N. Mahannah, 704-28S

R.T. McNew, 704-27S

J.D. Newell, 999-W

J.E. Occhipinti, 704-S

J.M. Pareizs, 773-A

D.K. Peeler, 999-W

B.R. Pickenheim, 999-W

F.C. Raszewski, 999-W

J.W. Ray, 704-S

S.H. Reboul, 773-42A

A.R. Shafer, 704-27S

H.B. Shah, 766-H

D.C. Sherburne, 704-S

M.E. Smith, 704-30S

M.E. Stone, 999-W 